\title{
PENGARUH PENDEKATAN KONSTRUKTIVISME TERHADAP AKTIVITAS DAN HASIL BELAJAR SISWA DALAM PEMBELAJARAN TEKS BIOGRAFI
}

\author{
Gede Artawan'1, ${ }^{*}$ Dewa Gede Yudi Setiawan² \\ 1 Universitas Pendidikan Ganesha \\ 2 Universitas Pendidikan Ganesha
}

\begin{abstract}
Abstrak
The purpose of this peneitian is to know the influence of constructivism approach to learning in the learning activity biographical text on eighth grade students at SMP Harapan Nusantara. To determine the effect of using constructivism approach to the learning outcomes in learning biography text in class VIII in SMP Harapan Nusantara. To determine the effect of using constructivism approach to the activities and achievement in learning biography text in class VIII in SMP Harapan Nusantara. Collecting data in this study conducted by the method of observation and testing methods / giving tasks to create a text biography. Observation methods used to assess student learning activities and testing methods used to assess student learning outcomes. In the test methods exist in the form of the initial test or pre-test, in the form of tests made text biography and post-test method is given at the end of the study. Final test or post-test given immediately after the students are given learning biography text using constructivism approach the experimental class and the control class conventional model. Based on test results obtained multivariate statistical values Pillai, Strace Wilk's Lambada Hotelling's Trace, and Roy'sLargest Root each with Fhitung $=50,720$ with significance $=0.05 \mathrm{dba}=2$ and obtained Ftabel $\mathrm{dbd}=80$ $=3,232$ at the $5 \%$ significance level. From the data obtained by analysis of $F$ larger than $\mathrm{F}$ table, the null hypothesis (HO) is rejected and the alternative hypothesis ( $\mathrm{Ha}$ ) is accepted. From the analysis of the data to test the hypothesis using multi-variate statistical variance of the activity and student learning outcomes can be concluded using kosntruktivisme approach has a significant effect on activity and learning outcomes in learning biography text in class VIII in SMP Harapan Nusantara.
\end{abstract}

\author{
Keywords: \\ constructivism \\ approach, learning \\ outcomes, biography
}

\section{PENDAHULUAN}

Pembelajaran bahasa Indonesia tidak bisa dilepaskan dari kegiatan menulis. Salah satu kegiatan menulis dalam pembelajaran bahasa Indonesia adalah mengarang. Mengarang adalah kegiatan yang lumrah dilakukan oleh siswa dalam pembelajaran bahasa Indonesia. Dalam kegiatan mengarang, siswa menulis berdasarkan tema sesuai dengan materi yang ada dalam buku ajar dan dituntun oleh guru/pendidik. Salah satu materi pembelajaran bahasa Indonesia yang berkaitan dengan kegiatan mengarang yang dilakukan oleh siswa kelas VIII berdasarkan kurikulum 2013 adalah materi pembelajaran teks biografi. Pembelajaran teks biografi merupakan pembelajaran yang mengupas riwayat hidup seseorang. Biografi adalah sebuah tulisan yang membahas mengenai kehidupan seseorang. Secara sederhana pengertian biografi adalah sebuah kisah riwayat seseorang. Biografi juga dapat diartikan sebagai suatu kisah atau keterangan perjalanan kehidupan seseorang bersumber dari kisah nyata, Kemendikbud (2014). Lazimnya yang diangkat untuk cerita boigrafi adalah kehidupan para tokoh atau orang yang terkenal dan memiliki prestasi. Jadi, pembelajaran teks biografi berisikan riwayat hidup seseorang dari kecil, masa jaya, masa tua, dan bahkan sampai akhir hayat diceritakan secara detail tanpa ada yang dikurangi atau dilebihkan dalam penggambarannya. Pembelajaran teks biografi akan memberikan pengaruh positif yang signifikan kepada pembaca karena cerita biografi menceritakan kehidupan seorang tokoh atau orang terkenal dalam menjalani kehidupan, sehingga pembaca merasa tertarik untuk mengetahui jalan kehidupan yang diceritakan pada teks biografi dan mampu 
menginspirasi pembaca untuk menjalani kehidupan seperti apa yang ditampilkan dalam teks biografi. Pembelajaran teks biografi sudah sangat tepat diterapkan di sekolah menengah pertamanya khususnya pada siswa kelas VIII, karena dengan usia yang tergolong menginjak masa remaja siswa kelas VIII sudah mampu membayangkan kejadian-kejadian yang mereka telah alami secara detail dan sesuai dengan realitas yang sebenarnya. Pembelajaran teks biografi sangat penting diberikan kepada siswa karena dalam materi teks biografi diceritakan kehidupan seorang tokoh dari awal sampai masa jaya, dan bahkan sampai akhir hayatnya. Dengan mengetahui secara detail kehidupan tokoh maka siswa akan mendapat inspirasi dari bacaan tersebut untuk bertindak dan mengambil keputusan yang tepat dalam menjalani kerasnya kehidupan. Pembelajaran teks biografi juga akan memperkaya pengetahuan dan wawasan para siswa mengenai kehidupan para tokoh yang diceritakan dalam teks biografi tersebut. Pembelajaran teks biografi akan mengasah kemampuan siswa dalam memahami karakter tokoh yang sebenarnya, menumbuhkan jiwa kritis dalam dirinya, dan mengasah kemampuan siswa membuat tulisan dalam bentuk karangan.

Pembelajaran teks biografi tidak hanya bermanfaat dalam proses pembelajaran formal di sekolah. Dengan menguasai materi pembelajaran teks biografi siswa setelah menyelesaikan pendidikan formal bisa memanfaatkan ilmu dari pembelajaran teks biografi untuk menjadi seorang penulis buku biografi atau menjadi seorang penulis puisi sesuai dengan karakter yang ada pada buku biografi. Pembelajaran teks biografi merupakan elemen penting dalam pembelajaran bahasa khususnya dalam keterampilan menulis. Pembelajaran teks biografi adalah pembelajaran mengarang atau menulis cerita tentang kehidupan seorang tokoh. Pembelajaran teks biografi sangat sesuai dengan kurikulum yang diterapkan saat ini yaitu kurikulum 2013 yang berbasis pada teks. Pembelajaran teks biografi yang diterapkan pada sekolah menengah pertama sudah sesuai dengan kurikulum dan kebutuhan siswa. Dalam pembelajaran teks biografi pendidik harus mampu menerapkan pendekatan yang cocok sesuai dengan karakteristik siswa. Setiap siswa memiliki karakteristi yang berbeda-beda, di sinilah peran seorang pendidik dalam melakukan pendekatan yang tepat untuk materi pembelajaran yang akan diberikan, sehingga semua karakteristik yang ada pada siswa mampu menyerap pendekatan pembelajaran yang diterapkan oleh guru.

Dalam menerapkan pembelajaran pendidik harus berani melakukan eksperimen dalam penerapan pendekatan pada proses pembelajaran. Penerapan pendekatan yang tepat dalam proses pembelajaran akan menjadikan aktivitas belajar mengajar menjadi menarik dan memberikan rasa nyaman pada siswa. Penerapan pendekatan yang tepat juga akan menghasilkan hasil belajar yang memuaskan. Dalam pembelajaran teks biografi pendekatan yang tepat diterapkan adalah pendekatan konstruktivisme. Sesuai dengan pengertiannya konstruktivisme oleh Dyle \& Haas (Putrayasa, 2010;2011: 95) menyatakan bahwa belajar menurut pandangan konstruktivis lebih diarakan pada terbentuknya makna pada diri pembelajar atas apa yang dipelajarinya berdasarkan pengetahuan dan pemahaman mereka sebelumnya. Pendekatan konstruktivisme yang berbasis inkuri digunakan sebagai salah satu pendekatan pembelajaran untuk mengungkap miskonsepsi yang terjadi pada siswa (Putrayasa, 2013). Dari pengertian pendekatan konstruktivisme menurut para ahli dapat disimpulkan pengetahuan yang didapat pembelajar harus dibentuk berdasarkan konsep yang ditemukan sendiri oleh pembelajar secara mandiri, sehingga pengetahuan yang didapatkan menjadi lebih bermakna. Dengan menggunakan pendekatan konstruktivisme dalam pembelajaran teks biografi akan memberikan pengaruh yang signifikan terhadap aktivitas dan hasil belajar siswa karena dengan penggunaan pendekatan konstruktivisme siswa dituntut aktif dalam proses pembelajaran.

Kemampuan pendidik dalam menerapkan pendekatan pembelajaran adalah kunci kesuksesan dalam proses pembelajaran itu sendiri. Pada era globalisasi dunia pendidikan terus mengalami perkembangan. Para pendidik dituntut untuk terus melakukan inovasi pada penerapan pembelajaran. Pendidik di era modern harus mampu menerapkan berbagai pendekatan dalam proses pembelajaran agar kegiatan belajar mengajar menjadi menarik dan tidak membosankan. Salah satu pendekatan yang relevan diterapkan di era modern seperti sekarang adalah pendekatan konstruktivisme.

Pengetahuan dalam pengertian konstruktivisme memandang bahwa pengetahuan merupakan konstruksi (bentukan) dari orang yang mengenal sesuatu (skemata) (Putrayasa, 2011: 96). Penerapan pendekatan konstruktivisme dalam pembelajaran akan memberikan kesempatan kepada siswa untuk mengkontruksi pengetahuan yang diberikan. Penerapan pendekatan konstruktivisme memberikan kesempatan seluas-luasnya kepada siswa selama aktivitas pembelajaran berlangsung. Dengan menerapkan pendekatan konstruktivisme dalam pembelajaran, siswa dituntun untuk menjadi siswa yang lebih mandiri dan mengurangi ketergantungan siswa pada guru selama proses pembelajaran berlangsung. Kemandirian siswa dalam proses pembelajaran akan menumbuhkan rasa percaya diri siswa untuk mencari informasi dari berbagai sumber dan menyimpulkan informasi tersebut, sehingga informasi yang disimpulkan menjadi pengetahuan yang mampu ditemukan oleh siswa itu sendiri. Selain melatih siswa 
untuk menjadi mandiri, penerapan pendekatan konstruktivisme dalam pembelajaran juga akan menjadikan proses pembelajaran itu menjadi lebih menarik dan variatif.

Menurut teori konstruktivisme, subjek aktif menciptakan struktur-struktur kognitif dalam interasiksinya dengan lingkungan (Putrayasa, 2011: 98). Proses pembelajaran yang selama ini berlangsung secara realitas di lapangan adalah pembelajaran yang berpusat pada guru. Pembelajaran yang selama ini berlangsung lebih dominan pada metode ceramah. Dengan pemberian pembelajaran dengan metode ceramah akan membuat siswa bosan selama proses pembelajaran, tidak ada banyak aktivitas yang bisa dilakukan siswa, dan membelenggu rasa percaya diri siswa dalam melakukan penemuan dan menyimpulkan informasi untuk dijadikan sebuah pengetahuan. Dengan permasalah klasik yang sudah berlangsung lama dalam pendidikan kita sudah saatnya pendidik melakukan inovasi dalam penggunaan pendekatan pembelajaran untuk meciptakan aktivitas pembelajaran pada siswa dan mendapatkan hasil belajar yang diharapkan. Dari hasil belajar yang diperoleh tersebut mampu menumbuhkan rasa percaya diri siswa untuk melakukan penemuan-penemuan pengetahuan dan menyimpulkan apa yang sudah siswa temukan selama proses pembelajaran berlangsung.

Dengan berbagai kekurangan dalam proses pembelajaran yang berlangsung selama ini, maka pendidik sudah saatnya menggunakan pendekatan yang baru yaitu pendekatan konstruktivisme dalam proses pembelajaran untuk memperoleh hasil belajar yang diharapkan. Dengan penggunaan pendekatan konstruktivisme diharapkan siswa mampu mengungkapkan dan mengembangkan ide yang siswa miliki. Penggunaan pendekatan konstruktivisme akan memupuk rasa keingintahuan siswa terhadap sesuatu yang baru yang berhubungan dengan pengetahuan. Selain memupuk rasa keingintahuan siswa dengan penerapan pendekatan konstruktivisme siswa akan memiliki rasa percaya diri untuk menggali dan menyimpulkan informasi dari pengetahuan yang mereka temukan. Hal ini, sesuai dengan karakteristik konstruktivisme yaitu; 1) mengembangkan strategi alternatif untuk memperoleh dan menganlisis informasi, 2) dimungkinkan persepektif jamak dalam proses belajar, dan 3) peran utama siswa dalam proses belajar, baik dalam mengatur atau mengendalikan proses berpikirnya sendiri maupun ketika berinteraksi dengan lingkungannya Winaputra 2007 (Putrayasa, 2011: 102).

Penerapan pendekatan konstruktivisme akan berpengaruh positif pada keaktifan siswa saat proses belajar mengajar. Pendidik yang mampu menerapkan pendekatan konstruktivisme dengan baik akan membuat proses belajar mengajar menjadi lebih menarik, meningkatkan aktivitas belajar, dan memacu daya pikir siswa. Penerapan pendekatan konstruktivisme membuka peluang kepada siswa untuk melakukan penemuan pengetahuan sesuai dengan pemahaman mereka. Pendekatan konstruktivisme menuntut siswa untuk aktif dalam menemukan permasalahan dan mencari solusi yang tepat dari permasalahan yang ditemukan.

Pendekatan konstruktivisme memberi peluang kepada pendidik untuk mengatasi berbagai persoalan yang terkait dengan rendahnya kualitas proses dan hasil pembelajaran, karena model ini dapat memfasilitasi keterlibatan aktif dan berkembangnya keterampilan berpikir siswa selama pembelajaran. Dengan alasan-alasan tersebut maka, pendekatan konstruktivisme sangat tepat diterapkan dalam proses belajar mengajar salah satunya dalam pembelajaran teks biografi. Dengan menggunakan pendekatan konstruktivisme dalam pembelajaran teks biografi, siswa mampu mengembangkan dirinya secara maksimal sesuai dengan kemampuan intelegensi yang dimiliki siswa.

Penerapan pendekatan konstruktivisme dalam pembelajaran teks biografi akan memberikan kesempatan kepada siswa secara eklektik, yaitu siswa dapat memanfaatkan teknik belajar apapun atau memilih yang terbaik dari berbagai sumber, asal tujuan belajar bisa dicapai. Dengan penerapan pendekatan konstruktivisme yang menuntut kreativitas motorik dan berpikir akan membuat proses pembelajaran menjadi lebih menantang. Proses pembelajaran yang memberi tantangan pada peserta didik akan membuat pembelajaran menjadi menarik dan menjauhkan siswa dari rasa bosan selama proses pembelajaran berlangsung. Dengan situasi seperti ini siswa akan merasa nyaman selama proses pembelajaran, dengan adanya rasa nyaman selama proses pembelajaran otomatis akan berdampak positif pada hasil belajar yang dicapai oleh siswa.

Penerapan pendekatan konstruktivisme dalam pembelajaran akan memancing kreativitas siswa dalam melakukan penemuan-penemuan pengetahuan, karena pendekatan konstruktivisme akan member kesempatan kepada siswa untuk mengembangkan pengetahuan mereka, tidak hanya bergantung pada guru dan orang lain. Kreativitas dan aktivitas siswa akan membantu mereka untuk berdiri sendiri dalam kehidupan kognitif siswa. Belajar lebih diarahkan pada experiental learning, yaitu adaptasi kemanusiaan berdasarkan pengalaman kongkret di laboratorium, diskusi dengan teman sejawat, yang kemudian dikontemplasikan dan dijadikan ide serta pengembangan konsep baru (Putayasa, 2011: 98).

Penerapan pendekatan konstruktivisme dalam pembelajaran sangat berlawanan dengan penerapan pendekatan pembelajaran yang dilakukan oleh pendidik selama ini (Suparno, 1996). Pada umumnya selama ini kegiatan proses pembelajaran berpusat pada pendidik. Pendidikan yang berpusat 
pada pendidik akan mengurangi aktivitas dan kreativitas siswa dalam proses pembelajaran. Dengan mengurangi aktivitas dan kreativitas siswa dalam proses pembelajaran, maka siswa tidak mampu bereksperimen untuk melakukan penemuan-penemuan pengetahuan. Untuk menjadi negara yang maju, khususnya dalam bidang pendidikan, maka warga negara atau khususnya siswa harus memiliki pemikiran yang kritis dan mampu melakukan penemuan-penemuan pengetahuan yang bisa menjadikan masyarakatanya hidup lebih sejahtera. Dengan penjabaran tersebut, maka pendekatan konstruktivisme memiliki nilai urgen yang tinggi untuk dapat diterapkan dalam proses pembelajaran di setiap sekolah sesuai dengan kebutuhan materi, karena pendekatan konstruktivisme akan memancing kerativitas dan aktivitas siswa selama pembelajaran sehingga siswa mampu mencari jawaban secara mandiri dari rasa penasaran dan keingintahuan mereka mengenai pengetahuan yang mereka sedang pelajari.

Metode pembelajaran yang digunakan saat ini masih bersifat konvensional dengan didukung oleh buku pegangan (hand-out) yang masih kental dengan gayatext book (Adnyana, 2015). Namun tuntutan zaman yang semakin kompleks menuntut para pendidik untuk selalu mengembangkan diri dengan melakukan inovasi pada pembelajaran. Tujuan dari inovasi yang dilakukan pendidik adalah untuk menciptakan sumber daya manusia yang berkualitas dan berbudi pekerti yang luhur. Untuk dapat menciptakan sumber daya manusia dan memiliki budi pekerti yang luhur salah satu kuncinya adalah pendidik harus mampu menciptakan suasana yang nyaman selama proses pembelajaran. Suasana yang nyaman dalam proses pembelajaran akan membuat siswa mampu menguasai materi pembelajaran secara maksimal baik dari segi teori maupun praktek.

Inovasi yang yang dilakukan pendidik dalam proses pembelajaran di kelas maupun di luas kelas yang mampu memancing aktivitas siswa untuk aktif dalam pembelajaran adalah salah satunya dengan menggunakan pendekatan konstruktivisme dalam pembelajaran, khususnya dalam pembelajaran teks biografi. Pendekatan konstruktivisme merupakan pendekatan inovasi yang dilakukan oleh para ahli di bidang pendidikan yang memiliki tujuan menjadikan siswa lebih mandiri dan mampu melakukan penemuan-penemuan pengetahuan untuk kesejahteraan manusia. Kalau pada zaman dahulu proses pembelajaran hanya berpusat pada guru dengan menggunakan metode ceramah, dengan pendekatan seperti ini siswa hanya bertindak dan memperoleh pengetahuan sesuai dengan apa yang telah diberikan oleh gurunya, sedangkan pembelajaran dengan menggunakan pendekatan konstruktivisme yang pembelajarannya berpusat pada siswa akan memberi kesempatan seluas-luasnya kepada siswa untuk berpikir dan melakukan sesuatu sesuai dengan ide yang mereka miliki.

Dengan menggunakan pendekatan konstruktivisme, maka akan terjadi pergeseran dalam proses pembelajaran dari proses pembelajaran yang berpusat pada guru menjadi pembelajaran yang berpusat pada siswa. Sesuai dengan pengertian konstruktivisme yaitu aplikasi model konstruktivis memungkinkan siswa untuk menguasai materi pelajaran secara lebih komperhensif dan bermakna, mengingat mereka terlibat secara aktif selama berlangsungnya pembelajaran (Putrayasa, 2010;2011: 96). Inovasi pembelajaran yang berpusat pada guru menjadi pembelajaran yang berpusat pada siswa memberikan pengaruh yang signifikan pada aktivitas dan hasil belajar siswa dalam pembelajaran teks biografi. Pembelajaran yang berpusat pada siswa akan memberi kesempatan pada siswa untuk learning to know, learning to do, dan learning together.

Penerapan pendekatan konstruktivisme adalah sebuah inovasi yang mampu menampilkan pembelajaran lebih menarik dan menantang bagi pembelajar atau siswa. Penerapan pendekatan konstruktivisme sangat tepat diterapkan pada pembelajaran teks biografi. Dalam materi pembelajaran teks biografi siswa dituntut aktif dari tahap awal, seperti: dalam menetukan jenis teks, pengertian teks biografi, dan mencari unsur-unsur pembentuk teks biografi. Inovasi dari pembelajaran dengan menggunakan pendekatan konstruktivisme pada pembelajaran teks biografi, siswa dapat mencari informasi dari berbagai sumber tentang materi pembelajaran teks biografi, sehingga siswa memiliki pengetahuan yang luas dari materi teks biografi.

Penerapan pendekatan konstruktivisme pada pembelajaran teks biografi akan menuntut siswa berperan secara aktif selama proses pembelajaran. Dengan keterlibatan siswa secara aktif selama proses pembelajaran akan menjadikan pembelajaran sangat menarik dan tidak membosankan. Siswa dapat berpikir bebas, berkreasi sesuai dengan ide yang dimiliki, dan terlibat secara aktif dalam proses pembelajaran. Disamping terlibat secara aktif dalam proses pembelajaran, dengan menerapkan pendekatan konstruktivisme pembelajar mampu lebih memahami teori yang mereka temukan dan kegiatan yang mereka lakukan. Pembelajaran yang berpusat pada siswa dan penuh dengan aktivitas siswa akan memacu siswa untuk melakukan penemuan-penemuan pengetahuan. Dengan proses pembelajaran seperti ini akan menarik minat siswa dalam belajar dan menjauhkan siswa dari rasa bosan.

Penelitian yang penulis buat mengenai penerapan pendekatan konstruktivisme dalam pembelajaran teks biografi sudah didukung data yang memadai. Siswa kelas VIII pada semester I mendapatkan materi pembelajaran teks biografi sesuai dengan kurikulum 2013 yang pembelajarannya 
dominan pada buku teks. Pada tahun ajaran 2016/2017 jumlah siswa kelas VIII di SMP Harapan Nusantara sangat memadai untuk dijadikan objek pendekatan konstruktivisme dalam pembelajaran teks biografi. Jadi, ketersediaan data dalam penelitian yang dilakukan penulis dalam membuat karya ilmiah yang berjudul "Pengaruh Penggunaan Pendekatan Konstruktivisme terhadap Aktivitas dan Hasil Belajar Siswa dalam Pembelajaran Teks Biografi pada Siswa Kelas VIII di SMP Harapan Nusantara " sudah tersedia.

Penulis menjadikan siswa kelas VIII di SMP Harapan Nusantara sebagai obyek penelitian dalam karya ilmiah yang berjudul "Pengaruh Penggunaan Pendekatan Konstruktivisme terhadap Aktivitas dan Hasil Belajar Siswa dalam Pembelajaran Teks Biografi pada Siswa Kelas VIII di SMP Harapan Nusantara didasari oleh beberapa alasan, yaitu; (1) Peneliti ingin mengetahui kemampuan siswa kelas VIII di SMP Harapan Nusantara dalam pembelajaran teks biografi dengan menggunakan pendekatan konstuktivisme; (2) SMP Harapan Nusantara adalah SMP swasta favorit yang ada di Kota Denpasar, sehingga dengan melakukan penelitian di SMP Harapan Nusantara peneliti mendapat gambaran tentang kemampuan siswa dalam menguasai materi pembelajaran teks biografi dengan menggunakan pendekatan konstruktivisme; (3) Di SMP Harapan Nusantara pada kelas VIII terdapat empat kelas yang setiap kelas memiliki kemampuan akademis yang merata pada setiap kelasnya. Peneliti melakukan penelitian di kelas VIII A sebagai kelas eksperimen dan VIII B sebagai kelas kontrol. Pemilihan kelas untuk penelitian dipilih secara acak. Kelas VIII A dijadikan kelas ekperimen dalam penelitian ini sudah mampu mewakili karakteristik keseluruhan kelas VIII yang ada di SMP Harapan Nusantara.

Penulis membuat karya ilmiah penerapan pendekatan konstruktivisme terhadap aktivitas dan hasil belajar siswa dalam pembelajaran teks biografi membatasi penelitiannya, yaitu hanya meneliti pengaruh penggunaan pendekatan konstruktivisme terhadap aktivitas dan hasil belajar siswa dalam pembelajaran teks biografi pada kelas VIII di SMP Harapan Nusantara. Dengan demikian penerapan pendekatan konstruktivisme sangat tepat diterapkan pada siswa kelas VIII pada tingkat sekolah menengah. Dengan penggunaan pendekatan konstruktivisme pada siswa kelas VIII pada sekolah menengah pertama akan memberikan pengaruh yang postif baik dari segi pemahaman akan teori, penerapan materi, dan aktivitas yang dilakukan berdasarkan teori yang ditemukan sendiri, sehingga siswa kelas VIII tidak hanya belajar untuk tahu secara teori saja, namun dapat melakukan sesuai dengan teori, dan mampu bekerja sama dalam mencari solusi dari permasalahan yang mereka hadapi.

\section{METODE PENELITIAN}

Penelitian ini menggunakan dua teknik analisis data yaitu analisis deskriptif dan analisis multivarian (Manova)satu jalur. Analisis deskriftif digunakan untuk menganalisis data aktivitas belajar dan hasil belajar siswa dalam pembelajaran teks biografi. Analisis Manova satu jalur digunakan untuk menguji hipotesis. Rancangan analisis data seperti pada tabel berikut.

Tabel 1 Tabel Rancangan Analisis Data Hasil Penelitian

\begin{tabular}{lllll}
\hline \multicolumn{1}{c}{ A1 } & & & A2 & \\
\hline Y1 & & Y2 & Y1 & Y2 \\
\hline
\end{tabular}

Keterangan :
$\mathrm{A} 1=$ Model Pembejaran Konstruktivisme
$\mathrm{A} 2=$ Model Pembelajaran Konvensional
$\mathrm{Y1}=$ Skor Aktivitas Belajar Siswa
Y2 = Skor Hasil Belajar Siswa

Informasi yang dicari dari dalam penelitian ini adalah gambaran umum aktivitas belajar siswa dan hasil belajar siswa dalam pembelajaran teks biografi. Gambaran umum tersebut berupa skor rata-rata, 
simpangan baku, skor terendah, skor tertinggi, modus, median, varian, dan rentangan. Dari data statistic deskriftif akan dibuat distribusi frekuensi histogram masing-masing variable.

Kegiatan analisis data terdiri atas kegiatan pengelolahan data dan analisis statistik. Kegiatan analisis data meliputi: (1) menyuting data secara manual. Penyutingan dilakukan karena kemungkinan ada datayang tidak jelas atau kesalahan dalam pengisian instrument sehingga tida memenuhi sayarat untuk dianalisis, (2) mentabulasi data, dan (3) mengelola data dalam bentuk sesuai kebutuhan. Dalam melakukan analisis data untuk penelitian ini ada tiga tahapan yang dilalui yakni: (1) tahap deskripsi data, (2) tahap pengujian prasyarat analisis, dan (30 tahap pengujian hipotesis.

\section{ANALISIS DAN PEMBAHASAN}

\section{Hasil Penelitian}

Objek dalam penelitian ini adalah aktivitas belajar siswa dan hasil belajar siswa dalam menyusun teks biografi sebagai akibat dari penerapan pendekatan konstruktivisme dan model pembelajaran konvensional dalam pembelajaran teks biografi pada siswa kelas VIII di SMP Harapan Nusantara. Penelitian ini menggunakan rancangan penelitian Pre-Experimental Designs (Nondesigns). Dengan demikian data yang diperoleh dalam penelitian ini adalah data observasi aktivitas belajar dan data pre-tes dan pos-tes hasil belajar dalam penyusunan teks biografi pada siswa kelas VIII di SMP Harapan Nusantara. Data dalam penelitian ini dapat dikelompokan menjadi: (1) aktivitas belajar siswa dalam pembelajaran teks biografi dengan menggunakan pendekatan konstruktivisme, (2) aktivitas belajar siswa dalam pembelajaran teks biografi dengan menggunakan model pembelajaran konvensional, (3) hasil belajar siswa dalam menyusun teks biografi dengan menggunakan pendekatan konstruktivisme, dan (4) hasil belajar siswa dalam menyusun teks biografi dengan menggunakan model pembelajaran konvensional. Masing-masing dari keempat distribusi tersebut menyajikan perhitungan ukuran sentral (rerata, modus, dan median), ukuran penyebaran data (standar devisiasi), tabel frekuensi, dan histogram.

Variabel hasil data aktivitas dan hasil belajar dalam menyusun teks biografi pada siswa kelas VIII di SMP Harapan Nusantara diukur dengan metode observasi dan tes kompetensi dalam bentuk tes unjuk kerja. Rubrik penilaian yang telah ditetapkan sebelumnya diperoleh skor mentah baik pada sampel kelas eksperimen maupun kelas kontrol. Rekapitulasi hasil perhitungan skor aktivitas dan hasil belajar dalam menyusun teks biografi pada siswa kelas VIII di SMP Harapan Nusantara dikhtisarkan sebagai berikut:

Berdasarkan data tabel di atas dapat dilihat bahwa aktivitas belajar siswa yang menggunakan pendekatan konstruktivisme memiliki rata-rata $=82,75$. Nilai rata-rata 82,75 termasuk kriteria aktif; median $=84 ;$ modus $=80$; standar devisiasi 5,57 ; varians $=31,11$; skor minimum $=70$; skor maksimum $=$ 90; dan rentangan 20. Sedangkan aktivitas belajar siswa kelompok model konvensional memiliki rata-rata $=72,25$ termasuk dalam kreteria cukup, median $=75$; mode $=78$; satandar deviasi; 6,75 ; varians $=45,57$; skor minimum $=55$; skor maksimum $=84$; dan rentangan 29 .

Hasil belajar siswa dalam menyusun teks biografi untuk tahap pre-tes pada kelas eksperimen memiliki rata-rata 62 termasuk dalam kreteria kurang; median $=62,5$; modus $=65$; standar deviasi $=7,82$; varians $=61,28$; skor minimum $=50$; skor maksimum $=85$; dan rentangan 35. Sedangkan hasil belajar menyusun teks biografi untuk tahap pre-tes pada kelas kontrol memiliki rata-rata 61,075 termasuk dalam kreteria kurang; median $=60$; modus $=65$; standar deviasi $=5,88$; varians $=34,63$; skor minimum $=50$; skor maksimum $=75$; dan rentangan 25 . Hasil belajar siswa dalam menyusun teks biografi untuk tahap pos-tes pada kelas eksperimen memiliki rata-rata 84,85 dengan kreteria baik; median $=85$; modus $=90$; standar deviasi $=6,56$; varians $=43,05$; skor minimum $=70$; skor maksimum $=95$; dan rentangan 25 . Sedangkan hasil belajar menyusun teks biografi untuk tahap pos-tes pada kelas kontrol memiliki rata-rata 72,125 dengan kreteria cukup; median $=72,5$; modus $=75$; standar deviasi $=6,39$; varians $=40,88$; skor minimum = 60; skor maksimum $=85$; dan rentangan 25 .

Dari hasil data di atas dapat disimpulkan bahwa rata-rata aktivitas dan hasil belajar siswa dalam menyusun teks biografi dengan menggunakan pendekatan konstruktivisme lebih besar daripada rata-rata aktivitas dan hasil belajar siswa dalam menyusun teks biografi dengan model pembelajaran konvensional.

\section{Deskripsi Kualifikasi Data Aktivitas Belajar Siswa}

Variabel aktivitas belajar siswa diukur dengan instrumen observasi aktivitas belajar. Dalam rubrik penilaian skor tertinggi untuk setiap butir instrumen adalah 4 , karena jumlah butir instrumen ada 9, maka perolehan skor tertinggi ideal adalah 4 X $9=36$ X $100: 36=100$. Skor terendah untuk setiap butir adalah 1, maka skor terendahnya ideal adalah 1 X $9=9$ X $100: 36=25$ Dengan demikian skor maksimal ideal untuk aktivitas belajar adalah 100 dan skor minimal ideal adalah 25 . Untuk mendapat nilai pada masing-masing interval tersebut ditempuh cara sebagai berikut. 
Terlebih dahulu kita hitung dulu mean ideal (Mi) dan standar devisiasi ideal (SDi). Mi = 1/2 X (skor maksimal ideal + skor minimal ideal) $=1 / 2 \mathrm{X}(100+25)=62$. SDi ${ }_{1 / 6} \mathrm{X}($ skor maksimal ideal - skor minimal ideal $)={ }_{1 / 6} X(100-25)=12,75$. Bedasarkan hasil hitungan tersebut selanjutnya disusun klsifikasi aktivitas belajar siswa sesuai dengan tabel konversi. Adapun hasil perhitungannya diperoleh sebagai berikut

Tabel 4. Hasil Perhitungan Kategori Aktivitas Belajar

\begin{tabular}{ccc}
\hline NO & SKOR & KATEGORI \\
\hline 1 & $\mathrm{X}>81,1$ & Sangat Aktif \\
2 & $68,0<\mathrm{X} \leq 81,1$ & Aktif \\
3 & $55,7<\mathrm{X} \leq 68,0$ & Cukup Aktif \\
4 & $42,9<\mathrm{X} \leq 55,7$ & Kurang Aktif \\
\hline
\end{tabular}

Berdasarkan tabel 4.4 di atas maka aktivitas belajar siswa dalam pembelajaran teks biografi pada kelas VIII di SMP Harapan Nusantara yang menggunakan pendekatan konstruktivisme mendapatkan skor $68,<\mathrm{X} \leq 81,1$ termasuk dalam kategori aktif, sedangkan aktivitas belajar siswa dalam pembelajaran teks biografi dengan menggunakan model konvensional mendapatkan skor 55, $7<\mathrm{X} \leq 68,0$ termasuk dalam kategori cukup aktif. Variabel aktivitas belajar siswa diukur dengan melakukan pengamatan terhadap seluruh siswa baik pada kelas eksperimen maupun kelas kontrol dengan menggunakan pedoman observasi.

Dari data yang ada dapat dijelaskan seluruh sampel yang diikutkan dalam penelitian baik pada kelas eksperimen maupun kontrol masing-masing berjumlah 40 orang. Perolehan rata-rata skor aktivitas belajar siswa pada kelas kontrol dengan metode pembelajaran konvensional sebesar 72,25 sedangkan pada kelas eksperimen dengan menggunakan pendekatan konstruktivisme sebesar 82,75. Distribusi Frekuensi Aktivitas Belajar Siswa Kelompok Model Pembelajaran KonstruktivismeData aktivitas belajar siswa pada kelas eksperimen dengan menggunakan pendekatan konstruktivisme mempunyai jumlah peserta $(N)=40$, skor minumum $=70$, skor maksimum $=90$, rentangan $=20$, banyak kelas $=4$, interval $=$ 2 , rata-rata $=82,75$, standar devisiasi $=557,811$, modus $=80$, dan median 84. Berdasarkan pedoman konversi analisis aktivitas belajar siswa, dapat disimpulkan bahwa aktivitas belajar siswa dengan menggunakan pendekatan kosntruktivisme berada dalam kualifikasi aktif. Distribusi data aktivitas belajar siswa pada kelompok belajar dengan menggunakan pendekatan konstruktivisme dapat diringkas seperti tabel beriku. memperlihatkan bahwa sebanyak 2,5\% siswa memperoleh skor sekitar rata-rata aktivitas belajar, sebanyak 42,5\% siswa memperoleh skor di bawah rata-rata, dan sebanyak 55\% siswa memperoleh skor di atas rata-rata. Untuk lebih jelas, berikut disajikan histogram dari frekuensi aktivitas belajar siswa dengan menggunakan pendektan konstruktivisme, seperti pada Gambar 1

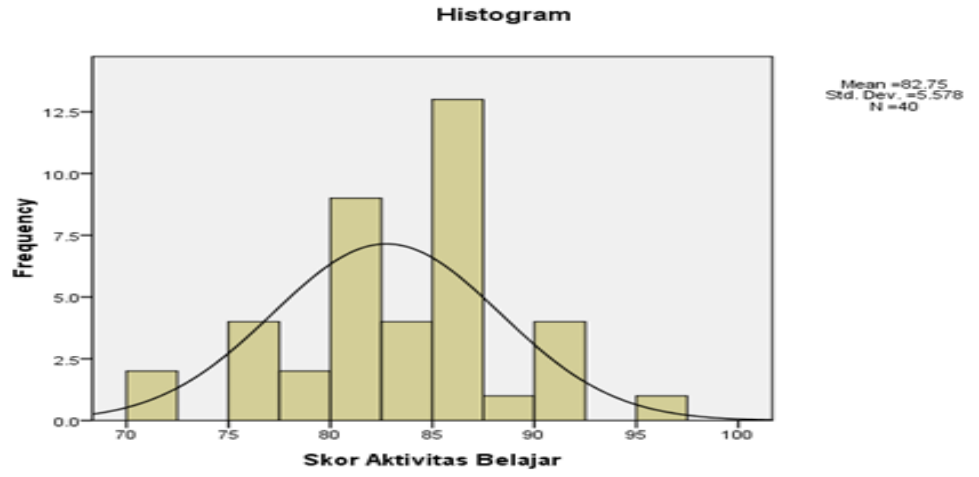

Gambar 1. Histogram Data Aktivitas Kelompok Belajar Siswa dengan Menggunakan Pendekatan Konstruktivisme.

Distribusi Frekuensi Aktivitas Belajar Siswa dengan Model Pembelajaran Konvensional. Dari aktivitas belajar siswa dengan menggunakan model pembelajaran konvensional mempunyai peserta $(\mathrm{N})=$ 40 , skor minimum $=55$, skor maksimum $=84$, rentangan $=29$, banyak kelas $=4$, interval $=2$, rata-rata $=$ 72,25 , standar devisiasi $=675,106$, modus $=78$, dan median $=75$. Berdasarkan pedoman konversi analisis aktivitas belajar siswa dapat disimpulkan bahwa aktivitas belajar siswa yang menggunakan model pembelajaran konvensional dalam kualifikasi cukup aktif. Distribusi frekuensi data dapat diringkas seperti tabel berikut. memperlihatkan bahwa sebanyak 17,5\% siswa memperoleh skor sekita rata-rata, sebanyak 30\% siswa memperoleh skor di bawah rata-rata, dan sebanyak 52,5\% siswa memperoleh skor di atas rata-rata. Supaya tampak lebih jelas, berikut disajikan histogram dari frekuensi aktivitas belajar dengan model pembelajaran konvensional, seperti pada gambar 2 . 


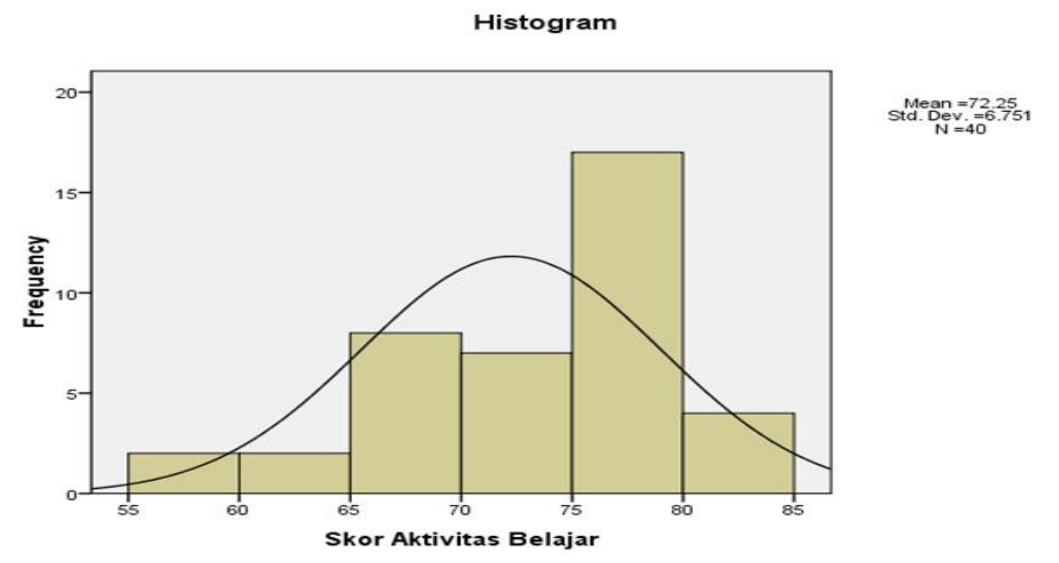

Gambar 2 Histogram Data Aktivitas Belajar Siswa dengan menggunakan Model Pembelajaran Konvensional.

\section{Deskripsi Kualifikasi Data Hasil Belajar Siswa dalam Menyusun Teks Biografi}

Variabel hasil belajar siswa dalam menyusun teks biografi diukur dengan tes unjuk kerja. Dalam rubrik penilaian skor tertinggi adalah 100 dan skor terendah adalah 0. Dengan demikian skor maksimal ideal untuk hasil belajar dalam menyusun teks biografi adalah 100 dan skor minimal ideal adalah 0 . Untuk pada masing-masing interval tersebut ditempuh cara sebagai berikut.

Terlebih dahulu hitung mean ideal (Mi) dan standar devisiasi ideal (SDi). Mi $=1 / 2 \mathrm{X}$ (skor maksimal idela + skor minimal ideal $)=1 / 2 X(100+0)=50 . S D i={ }_{1 / 6} X(100-0)=17$. Berdasarkan hasil perhitungan tersebut selanjutnya disusun kalsifikasi hasil belajar siswa dalam menyusun teks biografi sesuai dengan tabel konversi tersebut. Adapun hasil perhitungannya diperoleh sebagi berikut.

Tabel. 3 Kualifikasi Hasil Belajar Siswa dalam Menyusun Teks Biografi

\begin{tabular}{ccc}
\hline NO & SKOR & KATEGORI \\
\hline 1 & $\mathrm{X}>75$ & Sangat Aktif \\
2 & $58,5<\mathrm{X} \leq 75$ & Aktif \\
3 & $41,5<\mathrm{X} \leq 58,5$ & Cukup Aktif \\
4 & $24,5<\mathrm{X} \leq 41,5$ & Kurang Aktif \\
\hline
\end{tabular}

Berdasarkan tabel 4.8 di atas maka, hasil belajar siswa dalam menyusun teks biografi pada tahap pre-tes di kelas eksperimen memperoleh skor $24,5<\mathrm{X} \leq 41,5$ berada pada ketegori kurang baik, sedangkan hasil belajar siswa dalam menyusun teks biografi pada kelas kontrol juga mendapatkan skor $24,5<\mathrm{X} \leq 41,5$ dan juga berada pada kategori kurang baik.

Pada tahap pos-tes terjadi peningkatan hasil belajar siswa dalam menyusun teks biografi baik di kelas eksperimen yang menggunakan pendekatan konstruktivisme dalam proses pembelajarannya dan kelas kontrol yang mendapat tindakan dengan metode konvensional. Hasil belajar siswa dalam menyusun teks biografi pada tahap pos-tes di kelas eksperimen yang mendapat tindakan dengan menggunakan pendekatan konstruktivisme mendapatkan skor $58,5<\mathrm{X} \leq 75$ berada pada kategori baik, sedangkan di kelas kontrol dengan menggunakan metode konvensional mendapatkan skor $41,5<X \leq 58,5$ berada pada kategori cukup baik.

Variabel hasil belajar siswa dalam menyusun teks biografi diukur dengan tes kompetensi dalam bentuk tes unjuk kerja. Dengan menggunakan rubrik penilaian yang telah ditetapkan untuk memperoleh skor untuk sampel pada kelas eksperimen maupun kelas kontrol. Hasil pengukuran terhadap variabel hasil belajar siswa dalam menyusun teks biografi secara keseluruhan memberikan hasil seperti dalam tabel berikut ini.

Distribusi Frekuensi Hasil Belajar Siswa dalam Menyusun Teks Biografi pada Kelas Eksperimen. Dari data Tabel 4.9 tentang hasil belajar siswa dalam menyusun teks biografi pada kelas eksperimen tahap pre-tes mempunyai jumlah peserta $(\mathrm{N})=40$, skor minumum $=50$; skor maksimum 85 ; rentangan $=$ 35 ; banyak kelas $=4$; interval $=2$; rata-rata $=62$; standar devisiasi $=7,82$; modus $=65$; dan median $=62,5$. memperlihatkan bahwa sebanyak 22,5\% siswa memperoleh skor sekitar rata-rata, sebanyak $27,5 \%$ siswa memperoleh skor di bawah rata-rata, dan sebanyak $50 \%$ siswa memperoleh skor di atas rata-rata. Supaya tampak lebih jelas, berikut disajikan histogram dari frekuensi hasil belajar siswa dalam menyusun teks biografi pada kelas eksperimen untk pre-tes. 


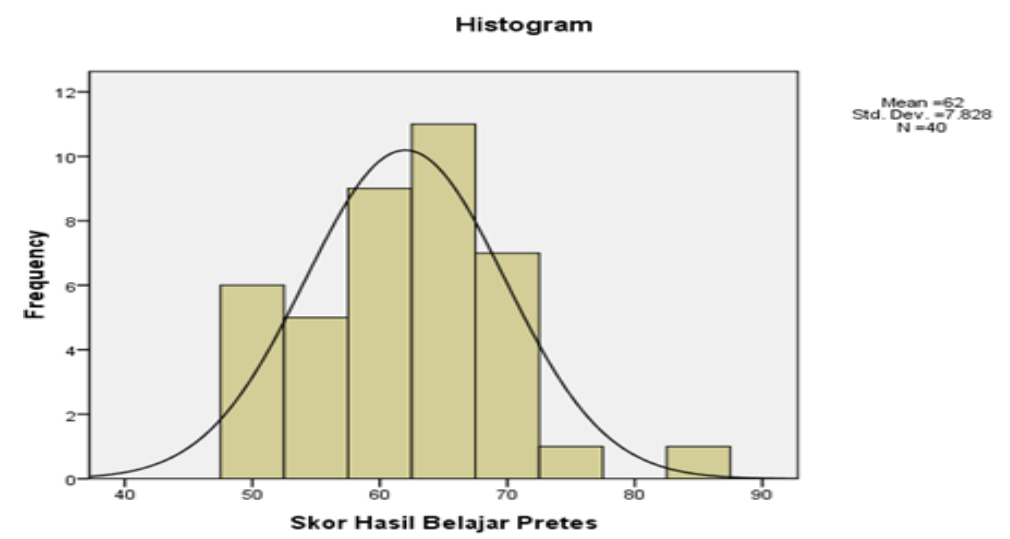

Gambar 3 Histogram Data Hasil Belajar Siswa dalam Menyusun Teks Biografi Pada Kelas Eksperimen Tahap Pre-Tes.

Dari data tentang hasil belajar siswa dalam menyusun teks biografi pada kelas eksprimen dengan menggunakan pendekatan konstruktivisme pada tahap pos-tes mempunyai jumlah peserta $(\mathrm{N})=40$, skor minumum $=70$; skor maksimum 95; rentangan $=25$; banyak kelas $=4$; interval $=2$; rata-rata $=84,85$; standar devisiasi $=6,56 ;$ modus $=90 ;$ dan median $=85$.

Histogram

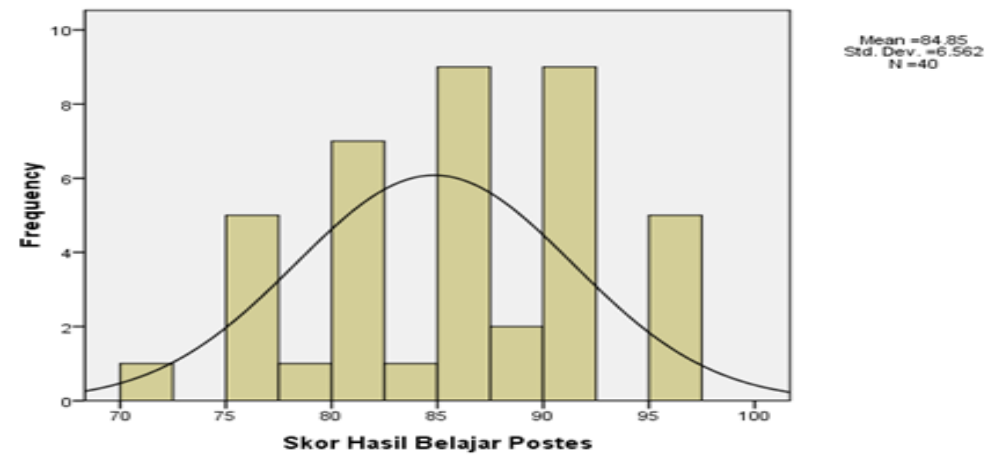

Gambar 4. Histogram Data Hasil Belajar Siswa dalam Menyusun Teks Biografi Kelas Eksperimen dengan Menggunakan Pendekatan Konstruktivisme Tahap Pos-Tes.

Distribusi Frekuensi Hasil Belajar Siswa dalam Menyusun Teks Biografi pada Kelas Kontrol. Berdasarkan distribusi frekuensi hasil belajar siswa dalam menyusun teks biografi pada kelas kontrol tahap pre-tes mempunyai jumlah peserta $(\mathrm{N})=40$, skor minimum $=50$; skor maksimum $=75$; rentangan $=$ 25 ; banyak kelas $=4$; interval 2 ; rata-rata $=61,075$; standar devisiasi $=5,88$; modus $=65$; dan median $=$ 60. memperlihatkan bahwa sebanyak $25 \%$ siswa memperoleh skor sekitar rata-rata, sebanyak $30 \%$ siswa memperoleh skor di bawah rata-rata, dan sebanyak $45 \%$ siswa memperoleh skor di atas rata-rata. Supaya lebih jelas berikut disajikan histogram hasil belajar siswa dalam menyusun teks biografi kelas kontrol tahap pre-tes seperti gambar 4.5.

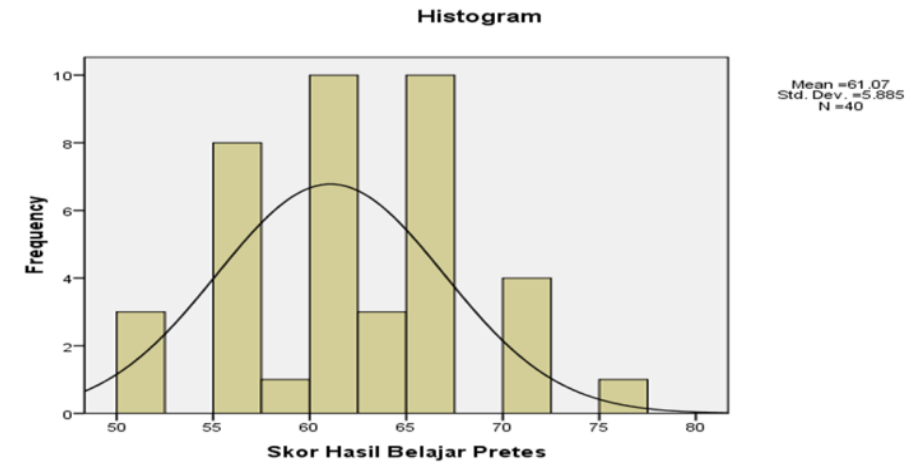

Gambar .5 Histogram Hasil Belajar Siswa dalam Menyusun Teks Biografi Kelas Kontrol pada Tahap Pre-Tes. 
Berdasarkan Tabel 4.9 data hasil belajar siswa dalam menyusun teks biografi kelas kontrol pada tahap pos-tes dengan model konvensional mempunyai jumlah peserta $(\mathrm{N})=40$, skor minimum $=60$; skor maksimum $=85$; rentangan $=25$; banyak kelas $=4$; interval 2 ; rata-rata $=72,125$; standar devisiasi $=6,39$; modus $=75$; dan median $=72,5$. Distribusi fre kuensi data.memperlihatkan bahwa sebanyak $25 \%$ siswa memperoleh skor sekitar rata-rata, sebanyak $25 \%$ siswa memperoleh skor di bawah rata-rata, dan sebanyak $50 \%$ siswa memperoleh skor di atas rata-rata. Supaya lebih jelas berikut disajikan histogram dari frekuensi hasil belajar siswa dalam menyusun teks biografi kelas kontrol pada tahap pos-tes dengan model pembelajaran konvensional.

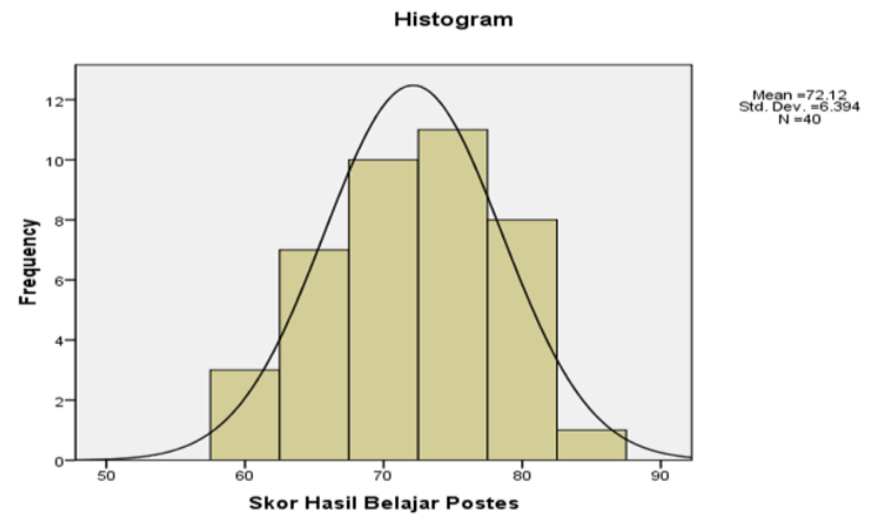

Gambar 6 Histogram Data Hasil Belajar Siswa dalam Menyusun Teks Biografi Kelas Kontrol dengan Model Konvensional pada Tahap Pos-Tes.

\section{Uji Prasyarat}

Pengujian hipotesis yang telah dirumuskan pada bab II, uji statistik dilakukan dengan Manova. Sebelum dilakukan uji hipotesis dengan model statistik tersebut, terlebih dahulu dilakukan uji asumsi sebagai prasyarat uji hipotesis, yaitu uji normalitas, uji homogenitas varians, dan uji multikolinieritas.

\section{Uji Normalitas Sebaran Data}

Uji normalitas dilakukan untuk menyakinkan bahwa uji statistik yang digunakan dalam pengujian hipotesis benar-benar bisa dilakukan. Hal ini penting karena bil data tidak normal, maka uji Manova tidak bisa dilakukan. Uji normalitas dalam penelitian ini menggunakan uji Kolmogrov-Smirnov yang dikenakan keempat data, yaitu: uji normalitas sebaran data menggunakan bantuan SPSS-21 for windows dan uji shapiro-wilk.Kriteria pengujian data berdistribusi normal jika angka signifikan yang dihasilkan dalam shapiro-wilk lebih besar dari 0,05. Berdasarkan hasil analisis diperoleh hasil data sebagai berikut. Dapat disimpulkan bahwa keempat kelompok data telah memiliki nilai signifikan di atas 0,05. Dengan demikian semua kelompok data telah berdistribusi normal, sehingga dapat dilanjutkan untuk analisis variansi berikutnya.

\section{Uji Homogenitas Varians}

Uji homogenitas varians dilakukan untuk menyakinkan bahwa perbedaan yang diperoleh dari uji Manova benar-benar berasal dari perbedaan antara kelompok, bukan berasal dari perbedaan yang terjadi di dalam kelompok. Pengujian homogenitas varians dalam penelitian ini dilakukan dengan uji kesamaan varian-kovarian menggunakan bantuan SPSS-21 for windows melalui uji Box's M untuk uji homogenitas secara bersama-sama dan uji Levene's untuk uji homogenitas secara terpisah (Santoso, 2001: 130). Kriteria pengjuian data memiliki matriks varians-kovariansyang dihasilkan yang sama (homogen) jika angka signifikan yang dihasilkan dalam uji Box's $M$ dan uji Levene's lebih dari 0,05 dan dalam hal ini data tidak berasal dari populasi yang homogen. Hasil uji homogenitas varians disajikan pada tabel berikut.

\section{Uji Multikolinieritas/Interkorelasi}

Uji Multikolinieritas aktivitas belajar siswa dengan hasil belajar siswa dalam meyusun teks biografi dilakukan dengan menggunakan bantuan SPSS- 21 for windows melalui uji korelasi Pearson (Santoso, 2001). Pedoman dalam memberikan interpretasi koefisiensi korelasi adalah jika koefisiensi korelasi berada di bawah 0,4 maka koefisiensi korelasi tergolong rendah, sehingga dapat dikatakan bahwa antara aktivitas belajar dan hasil belajar siswa tidak berhubungan. Adapun hasilnya dengan menggunakan SPSS diperoleh hasil sebagai berikut. 
Tabel 4 Hasil Pengujian Korelasi antar Variabel dengan Bantuan SPSS

Correlations

\begin{tabular}{|c|c|c|c|c|}
\hline & & $\begin{array}{c}\text { Skor Aktivitas } \\
\text { Belajar }\end{array}$ & $\begin{array}{c}\text { Skor Hasil } \\
\text { Belajar Pretes }\end{array}$ & $\begin{array}{c}\text { Skor Hasil } \\
\text { Belajar Postes }\end{array}$ \\
\hline \multirow[t]{5}{*}{$\begin{array}{l}\text { Skor } \\
\text { Belajar }\end{array}$} & $\begin{array}{l}\text { Aktivitas Pearson } \\
\text { Correlation }\end{array}$ & 1 & .202 & $.555^{* *}$ \\
\hline & Sig. (2-tailed) & & .072 & .000 \\
\hline & $\begin{array}{l}\begin{array}{l}\text { Sum of Squares } \\
\text { and } \\
\text { products }\end{array} \\
\text { Cross- }\end{array}$ & 5196.000 & 893.500 & 3230.500 \\
\hline & Covariance & 65.772 & 11.310 & 40.892 \\
\hline & $\mathrm{N}$ & 80 & 80 & 80 \\
\hline \multirow[t]{5}{*}{$\begin{array}{l}\text { Skor Hasil } \\
\text { Pretes }\end{array}$} & $\begin{array}{l}\text { il Belajar Pearson } \\
\text { Correlation }\end{array}$ & .202 & 1 & $.461^{* *}$ \\
\hline & Sig. (2-tailed) & .072 & & .000 \\
\hline & $\begin{array}{l}\begin{array}{l}\text { Sum of Squares } \\
\text { and } \\
\text { products }\end{array} \\
\text { Cross- }\end{array}$ & 893.500 & 3757.888 & 2281.038 \\
\hline & Covariance & 11.310 & 47.568 & 28.874 \\
\hline & $\mathrm{N}$ & 80 & 80 & 80 \\
\hline \multirow[t]{5}{*}{$\begin{array}{l}\text { Skor Hasi } \\
\text { Postes }\end{array}$} & $\begin{array}{l}\text { il Belajar Pearson } \\
\text { Correlation }\end{array}$ & $.555^{* *}$ & $.461^{* *}$ & 1 \\
\hline & Sig. (2-tailed) & .000 & .000 & \\
\hline & $\begin{array}{l}\text { Sum of Squares } \\
\text { and } \\
\text { products }\end{array}$ & 3230.500 & 2281.038 & 6511.987 \\
\hline & Covariance & 40.892 & 28.874 & 82.430 \\
\hline & $\mathrm{N}$ & 80 & 80 & 80 \\
\hline
\end{tabular}

**. Correlation is significant at the 0.01 level (2-tailed).

Berdasarkan tabel $4.16 \mathrm{di}$ atas diperoleh hasil korelasi antar variabel aktivitas belajar dan hasil belajar siswa sebesar =0,555. Hasil ini lebih kecil dari 0,40. Dengan demikian berdasarkan pedoman nilai interpretasi, nilai korelasi ini tergolong rendah atau dapat dikatakan antara variabel aktivitas belajar dan hasil belajar siswa tidak berhubungan, sehingga uji statistik dapat dilanjutkan.

Bertitik tolak dari hasil uji normalitas, homogenitas, dan multikolinieritas data aktivitas belajar dan hasil belajar siswa dalam menyusun teks biografi dapat dikatakan bahwa persyaratan untuk pengujian hipotesis dengan uji Manova dapat dipenuhi. Oleh karena itu pengujian hipotesis dapat dilanjutkan.

\section{Uji Hipotesis}

Terdapat pengaruh penggunaan pendekatan konstruktivisme terhadap aktivitas belajar dalam pembelajaran teks biografi pada siswa kelas VIII di SMP Harapan Nusantara. Hipotesis pertama yang diuji adalah pengaruh penggunaan pendekatan kosntruktivisme terhadap aktivitas belajar dalam pembelajaran teks biografi pada siswa kelas VIII di SMP Harapan Nusantara. Hipotesis tersebut dijabarkan menjadi:

$\mathrm{H}_{0}: \mu_{\mathrm{A} 1 \mathrm{Y} 1}=\mu_{2 \mathrm{Y} 1}$

Ha $: \mu_{\mathrm{A} 1 \mathrm{Y} 1} \neq \mu_{2 \mathrm{Y} 1}$

Keterangan

$\mu_{\mathrm{A} 1 \mathrm{Y} 1}=$ Data aktivitas belajar siswa dengan menggunakan pendekatan konstruktivisme.

$\mu_{2 \mathrm{Y} 1}=$ Data aktivitas belajar siswa dengan menggunakan model pembelajaran konvensional.

Analisis yang digunakan untuk menguji hipotesis tersebut adalah analisis Manova. Hasil uji hipotesis dengan menggunakan analisis varians diringkas pada tabel berikut. 
Tabel 5 Ringkasan Manova untuk Data Aktivitas Belajar Siswa

Tests of Between-Subjects Effects

Dependent Variable:Skor Aktivitas Belajar

\begin{tabular}{|llccccc}
\hline \multicolumn{2}{l}{ Source } & & Type III Sum of & & & \\
Squares & Df & Mean Square & F & Sig. \\
\hline Intercept & Hypothesis & 480500.000 & 1 & 480500.000 & 217.914 & .043 \\
& Error & 2205.000 & 1 & $2205.000^{\mathrm{a}}$ & & \\
\multirow{3}{*}{ Model } & Hypothesis & 2205.000 & 1 & 2205.000 & 57.503 & .000 \\
& Error & 2991.000 & 78 & $38.346^{\mathrm{b}}$ & & \\
\hline
\end{tabular}

a. MS(Model)

b. MS(Error)

Berdasarkan tabel 4.17 dapat diketahui bahwa nilai $\mathrm{F}_{\text {hitung }}=217,914$. Dengan menggunakan $\mathrm{db}_{\mathrm{a}}=$ 2 dan $\mathrm{db}_{d}=80$ didapatkan harga $F_{\text {tabel }}=3,323$. Pada taraf signifikasi 5\%. Karena $F_{\text {hitung }}$ lebih besar dari $F_{\text {tabel }}$ maka hipotesis nol $\left(\mathrm{H}_{0}\right)$ ditolak dan hipotesis alternatif $\left(\mathrm{H}_{\mathrm{a}}\right)$ diterima. Jadi dapat disimpulkan bahwa terdapat pengaruh yang signifikan pada aktivitas belajar siswa yang menggunakan pendekatan konstruktivisme dari pada model pembelajaran konvensional. Rata-rata aktivitas belajar siswa dengan menggunakan pendekatan konstruktivisme sebesar 82, 75 lebih tinggi dari aktivitas belajar siswa dengan menggunakan model konvesional sebesar 72, 25. Oleh karena itu, penggunaan pendekatan konstruktivisme berpengaruh positif terhadap aktivitas belajar siswa dan lebih unggul daripada penggunaan penerapan pembelajaran konvensional.

Terdapat pengaruh penggunaan pendekatan konstruktivisme terhadap hasil belajar dalam pembelajaran teks biografi pada siswa kelas VIII di SMP Harapan Nusantara.MHipotesis kedua yang diuji adalah pengaruh penggunaan pendekatan konstruktivisme terhadap hasil belajar dalam pembelajaran teks biografi pada siswa kelas VIII di SMP Harapan Nusantara. Hipotesis tersebut dijabarkan menjadi:

$\mathrm{H}_{0}: \quad \mu_{\mathrm{A} 1 \mathrm{Y} 2}=\mu_{\mathrm{A} 2 \mathrm{Y} 2}$

$\mathrm{H}_{\mathrm{a}}: \mu_{\mathrm{A} 1 \mathrm{Y} 2} \neq \mu_{\mathrm{A} 2 \mathrm{Y} 2}$

Keterangan

$\mu_{\mathrm{A} 1 \mathrm{Y} 2}=$ data hasil belajar siswa dalam menyusun teks biografi dengan menggunakan pendekatan konstruktivisme.

$\mu_{\mathrm{A} 2 \mathrm{Y} 2}=$ data hasil belajar siswa dalam menyusun teks biografi dengan menggunakan model konvensional.

Analisis yang digunakan untuk menguji hipotesis tersebut adalah analisis Manova. Hasil uji hipotesis dengan menggunakan analisis varians yang diringkas pada tabel berikut.

Tabel 6 Ringkasan Manova untuk Data Kemampuan Hasil Belajar Siswa dalam Menyus Biografi.

Dependent Variable:Skor Hasil Belajar (Univariate Tests)

\begin{tabular}{|c|c|c|c|c|c|c|}
\hline Source & & $\begin{array}{c}\text { Type III Sum of } \\
\text { Squares }\end{array}$ & Df & $\begin{array}{l}\text { Mean } \\
\text { Square }\end{array}$ & $\mathrm{F}$ & Sig. \\
\hline \multirow[t]{2}{*}{ Intercept } & Hypothesis & 492823.012 & 1 & $\begin{array}{c}492823.01 \\
2\end{array}$ & $\begin{array}{c}152.17 \\
6\end{array}$ & .001 \\
\hline & Error & 3238.513 & 1 & $3238.513^{a}$ & & \\
\hline \multirow[t]{2}{*}{ Model } & Hypothesis & 3238.513 & 1 & 3238.513 & 77.167 & .000 \\
\hline & Error & 3273.475 & 78 & $41.968^{b}$ & & \\
\hline
\end{tabular}
a. MS(Model)
b. MS(Error)

Berdasarkan tabel dapat diketahui bahwa nilai $\mathrm{F}_{\text {hitung }}$ adalah 152, 176. Dengan menggunakan $\mathrm{db}_{\mathrm{a}}=2$ dan $\mathrm{db}_{\mathrm{d}}=80$ didapatkan nilai $\mathrm{F}_{\text {tabel }}$ adalah 3,232. Pada taraf signifikasi 5\%. Karena $\mathrm{F}_{\text {hitung }}$ lebih besar dari $\mathrm{F}_{\text {tabel }}$ maka hipotesis $0\left(\mathrm{H}_{0}\right)$ ditolak dan hipotesis alternatif $\left(\mathrm{H}_{\mathrm{a}}\right)$ diterima. Jadi dapat disimpulkan bahwa terdapat pengaruh penggunaan pendekatan konstruktivisme terhadap hasil belajar siswa dalam menyusun teks biografi. Rata-rata hasil belajar siswa dalam menyusun teks biografi dengan menggunakan 
pendekatan konstruktivisme sebesar 84,85 lebih besar dari rata-rata hasil belajar dalam menyusun teks biografi pada kelompok siswa dengan menggunakan model pembelajaran konvensional sebesar 72,125. Oleh karena itu, penggunaan pendekatan konstruktivisme berpengaruh positif terhadap hasil belajar siswa dan lebih unggul daripada penerapan model pembelajaran konvensional. Terdapat pengaruh penggunaan pendekatan konstruktivisme terhadap aktivita dan hasil belajar dalampembelajaran teks biografi pada siswa kelas VIII di SMP Harapan Nusantara.

Tabel 7 Ringkasan Manova untuk Data Aktivitas dan Hasil Belajar Siswa dalam Pembelajaran Teks Biografi.

Multivariate Tests

\begin{tabular}{llccccc}
\hline Effect & & Value & F & Hypothesis df & Error df & Sig. \\
\hline Intercept & Pillai's Trace & .975 & $1.005 \mathrm{E} 3^{\mathrm{a}}$ & 3.000 & 76.000 & .000 \\
& Wilks' Lambda & .025 & $1.005 \mathrm{E} 3^{\mathrm{a}}$ & 3.000 & 76.000 & .000 \\
& Hotelling's Trace & 39.659 & $1.005 \mathrm{E} 3^{\mathrm{a}}$ & 3.000 & 76.000 & .000 \\
& Roy's Largest Root & 39.659 & $1.005 \mathrm{E} 3^{\mathrm{a}}$ & 3.000 & 76.000 & .000 \\
\multirow{4}{*}{ Model } & Pillai's Trace & .667 & $50.720^{\mathrm{a}}$ & 3.000 & 76.000 & .000 \\
& Wilks' Lambda & .333 & $50.720^{\mathrm{a}}$ & 3.000 & 76.000 & .000 \\
& Hotelling's Trace & 2.002 & $50.720^{\mathrm{a}}$ & 3.000 & 76.000 & .000 \\
& Roy's Largest Root & 2.002 & $50.720^{\mathrm{a}}$ & 3.000 & 76.000 & .000 \\
\hline
\end{tabular}

a. Exact statistic

b. Design: Intercept + Model

Berdasakan hasil uji multivariate yang disajikan pada tabel tersebut, diperoleh nilai-nilai statistik Pillai's Trace, Wilk"s Lambada, Hotelling's Trace, dan Roy's Largest Root masing-masing dengan $\mathrm{F}_{\text {hitung }}=50$, 720 dengan signifikasi $=0,05$. Hasil ini dijadikan dasar dalam mengambil keputusan. Dengan menggunakan $d_{b}=2$ dan $d b_{d}=80$ didapatkan $F_{\text {tabel }}=3,232$ pada taraf signifikasi $5 \%$, karena $F_{\text {hitung lebih }}$ besar dari $\mathrm{F}_{\text {tabel }}$ maka hipotesis $0\left(\mathrm{H}_{0}\right)$ ditolak dan hipotesis alternatif $\left(\mathrm{H}_{\mathrm{a}}\right)$ diterima. Jadi dapat disimpulkan bahwa terdapat pengaruh penggunaan pendekatan konstruktivisme aktivitas dan hasil belajar dalam pembelajaran teks biografi pada siswa kelas VIII di SMP Harapan Nusantara. Rata-rata aktivitas dan hasil belajar siswa yang menggunakan pendekatan konstruktivisme lebih tinggi dari aktivitas dan hasil belajar siswa dengan menggunakan model pembelajaran konvensional.

\section{Pembahasan}

Pembahasan hasil penelitian yang akan dipaparkan pada bagian ini adalah hasil analisis deskriptif dan hasil analisis statistik yang meliputi variabel bebas yaitu penggunaan pendekatan konstruktivisme yang merupakan variabel perlakuan, dan variabel terikat yaitu aktivitas dan hasil belajar siswa dalam pembelajaran teks biografi. Fokus pembahasan adalah analisis statistik yang menyangkut pengaruh variabel bebas terhadap variabel terikat.

Hasil analisis hipotesis pertama menyatakan bahwa kelompok siswa yang belajar dengan menggunakan pendekatan konstruktivisme hasilnya lebih baik daripada aktivitas belajar siswa dalam pembelajaran teks biografi daripada kelompok siswa yang belajar dengan menggunakan metode pembelajaran konvensional. Hasil analisis data tersebut tampak pada Tabel 4.3 yang menunjukan bahwa aktivitas belajar siswa yang menggunakan pendekatan konstruktivisme dengan skor rata-rata 82,75 sedangkan aktivitas belajar siswa yang menggunakan model pembelajaran konvensional memiliki skor rata-rata 72,25 . Hal ini disebabkan dalam pembelajaran konstruktivisme khususnya pembelajaran bahasa Indonesia dalam materi teks biografi, aktivitas belajar yang diamati yaitu ada sembilan aspek aktivitas menurut Budiyani (2009) yaitu; (1) memperhatikan apa yang disampaikan guru, (2) menjawab pertanyaan dari guru, (3) mengerjakan tugas yang diberikan oleh guru, (4) bekerja sama dengan teman satu kelompok, (5) mendiskusikan masalah yang dihadapi dalam kegiatan belajar mengajar, (6) bertukar pendapat antar teman dalam kelompok, (7) mengambil keputusan dari semua jawaban yang dianggap benar, (8) mempresentasikan jawaban di depan kelas, dan (9) merespon jawaban teman. Kesembilan aspek dalam aktivitas belajar ini yang ditekankan adalah kemandirian siswa dalam pembelajaran. Oleh karena itu diberikan kebebasan, maka para siswa akan lebih menaruh minat pada pembelajaran, lebih bergairah, bersemangat, dan berani dalam mengungkapkan ide yang dimiliki selama proses pembelajaran berlangsung. Dengan pembelajaran menggunakan pendekatan konstruktivisme siswa memperoleh pengetahuan dengan konsepnya sendiri melalui pengamatan, mengerjakan, dan menyimpulkan dari hasil 
pengamatan yang telah dilakukan.

Bila model pembelajaran konvensional yang diterapkan di dalam kelas, maka akan terlihat peran teman sebaya dan guru dalam membentuk aktivitas belajar sehingga aktivitas belajar menjadi tidak optimal karena siswa dalam memperoleh pengetahuan menggunakan konsep guru ataupun teman sebayanya. Demikian pula suasana kelas dengan menggunakan model pembelajaran konvensional tidak banyak memberikan kesempatan kepada siswa untuk mengembangkan aktivitas belajar, hal ini dapat dilihat saat diskusi kelompok siswa hanya mendiskusikan hal-hal yang ada dalam LKS saja dan tidak ada kebebasan berpendapat sehingga terlihat kurang aktif. Penerapan pembelajaran konvensional di dalam kelas membuat siswa menjadi pasif ini diakibatkan karena siswa ketika akan berkativitas cenderung menunggu arahan dari guru.

Hasil analisis hipotesis kedua menyatakan bahwa kelompok siswa yang dalam pembelajarnya menggunakan pendekatan konstruktivisme hasilnya lebih baik daripada hasil belajar siswa dalam menyusun teks biografi pada kelompok siswa yang dalam pembelajarannya menggunakan metode konvensional. Hasil perhitungan tersebut menunjukan bahwa hasil belajar siswa dalam menyusun teks biografi dengan menggunakan pendekatan konstruktivisme pada proses pembelajarannya memiliki ratarata sebesar 84,85, sedangkan hasil belajar siswa dalam menyusun teks biografi dengan menggunakan metode konvensional dalam proses pembelajarannya memiliki rata-rata sebesar 72,125. Lebih baiknya hasil belajar siswa dalam menyusun teks biografi dengan menggunakan pendekatan konstruktivisme dalam proses pembelajaran disebabkan oleh beberapa faktor, yaitu; siswa menggunakan konsepnya sendiri dalam memperoleh pengetahuan, siswa diberi kebebasan dalam proses menemukan pengetahuan, munculnya keberanian siswa dalam menggungkapkan ide, dan mampu mengambil kesimpulan dari pengetahuan yang didukung oleh fakta. Untuk menapatkan hasil teks biografi yang baik maka sudah tentu siswa harus rajin membaca. Dengan rajin membaca akan menambah wawasan dan pengetahuan siswa, sehingga hasil belajar siswapun akan menjadi maksimal. Kegiatan menulis pada dasarnya merupakan kegiatan produktif dan ekspresif yang memerlukan daya imajinasi dari penulisnya. Dengan menggunakan penerapan model pembelajaran konvensional di dalam kelas menjadikan siswa cenderung tidak aktif karena siswa terpaku dengan ceramah guru yang lebih banyak teori dalam menyusun teks biografi dan siswa tidak diberikan kesempatan dalam mengungkapkan ide maupun kesempatan untuk mandiri selama proses pembelajaran berlangsung. Tanpa diberi kebebasan dalam mengungkapkan ide dan berekspresi maka hasil belajar dalam menyusun teks biografi tidak akan maksimal, karena dalam menyusun teks biografi siswa harus mempu mengungkapkan ide dan ekspresinya untuk menghasilkan sebuah karya tulis yang bagus. Dengan proses pembelajaran yang terpaku pada instruksi guru, maka siswa kemampuan siswa dalam berimajinasi dan berekspresi menjadi terbelenggu sehingga hasil karya tulis siswa tidak menjadi maksimal.

Hasil analisis hipotesis ketiga menyatakan bahwa rata-rata aktivitas belajar siswa pada kelas eksperimen dengan menggunakan pendekatan konstruktivisme sebesar 82,75 termasuk dalam kategori aktif, sedangkan rata-rata aktivitas belajar siswa pada kelas kontrol dengan menggunakan metode konvensional sebesar 72,25 termasuk dalam kategori cukup aktif. Hasil belajar siswa pada kelas eksperimen pada tahap post-tes setelah mendapatkan tindakan pembelajaran dengan menggunakan pendekatan konstruktivisme memperoleh rata-rata sebesar 84,85 termasuk dalam kategori baik, sedangkan hasil belajar pada kelas kontrol yang mendapatkan tindakan pembelajaran dengan menggunakan metode konvensional memperoleh rata-rata 72,125 termasuk dalam kategori cukup baik. Dari hasil analisis data ini, maka aktivitas dan hasil belajar siswa dalam pembelajaran teks biografi pada kelas eksperimen yang menggunakan pendekatan konstruktivisme lebih baik daripada kelas kontrol yang menggunakan metode konvensional. Dengan demikian, secara keseluruhan temuan dalam penelitian ini memberikan gambaran bahwa terdapat pengaruh yang signifikan penggunaan pendekatan konstruktivisme terhadap aktivitas dan hasil belajar siswa dalam pembelajaran teks biografi pada siswa kelas VIII di SMP Harapan Nusantara. Penggunaan pendekatan konstruktivisme lebih baik daripada penggunaan metode konvensional untuk aktivitas dan hasil belajar siswa dalam menyusun teks biografi. Oleh karena, penggunaan pendekatan konstruktivisme dalam proses pembelajaran khususnya dalam pembelajaran teks biografi sangat disarankan untuk digunakan karena pendekatan konstruktivisme memberikan peluang kepada siswa untuk berpartisifasi aktif dalam proses pembelajaran, siswa dapat mengembangkan ide yang dimilikinya untuk dijadikan pengetahuan yang didukung dengan fakta hasil dari temuan selama proses pembelajaran, siswa memiliki keberanian dalam menyimpulkan suatu permasalahan, dan mampu menemukan konsep pengetahuan sesuai dengan cara mereka sendiri dan tidak memakai konsep orang lain. Dengan alasan-alasan tersebut maka secara otomatis siswa akan memperoleh pengalaman belajar yang lebih bermakna dan lama melekat dalam pikiran mereka. Dengan lamanya informasi yang melekat pada memori siswa, tentu akan berdampak pula terhadap hasil belajar siswa. Dapat pula dikatakan siswa dapat belajar memecahkan masalah secara adil, kritis, terbuka, dan 
obyektif. Semua kegiatan ini berpengaruh terhadap aktivitas belajar siswa.

Menggunakan pendekatan konstruktivisme dalam proses pembelajaran dapat membangkitkan rasa percaya diri siswa dalam mengambil kesimpulan untuk dijadikan pengetahuan. Dengan membangkitkan rasa percaya diri siswa maka penggunaan pendekatan konstruktivisme secara otomatis berpengaruh pada pembentukan mental siswa. Pembentukan mental merupakan awal pembentukan karakter bagi siswa. dalam membentuk dan mengembangkan mental skema, di mana mental skema ini dapat digunakan siswa untuk mengorganisasikan dan membangun pengetahuannya sesuai dengan skema mentalnya, sehingga mencapai taraf pemahaman yang maksimal. Dengan menggunakan pemahamannya siswa menganalisis dan menafsirkan informasi yang baru diterimanya, selanjutnya dituangkan dalam suatu tulisan dan diorganisir menjadi karya tulis yang berbentuk pengetahuan. Kompetensi lainnya yang dapat dibentuk dengan penggunaan pendekatan konstruktivisme dalam proses pembelajaran adalah kompetensi komunikasi, kerja sama dalam tim, memecahkan masalah, mengembangkan konsep toleransi, membangun serta mengembangkan konsep diri, membangun etos kerja yang mandiri, dan mampu mengeksplorasi sumber belajar dilingkungannya.

Hasil penelitian Pengaruh Penggunaan Pendekatan Konstruktivisme terhadap Aktivitas dan Hasil Belajar Siswa dalam Pembelajaran Teks Biografi pada Siswa Kelas VIII di SMP Harapan Nusantara nampaknya sejajar dengan penelitian yang relevan dilakukan oleh: (1) Khomarudin (2012) yang menunjukan bahwa penerapan pendekatan konstruktivisme memiliki pengaruh terhadap peningkatan hasil belajar siswa dalam pelajaran bahasa Indonesia pada materi menulis cerita. Penelitian ini sejajar hasil analisis hipotesis kedua, yaitu terdapat pengaruh yang signifikanpenggunaan pendekatan konstruktivisme terhadap hasil belajar dalam pembelajaran teks biografi pada siswa kelas VIII di SMP Harapan Nusantara. (2) Pulapi Purnamawati (2010) yang menyatakan bahwa penggunaan pendekatan konstruktivisme mempunyai pengaruh terhadap kemampuan berpikir kreatif siswa dalam pembelajaran kimia. Penelitian ini sejajar dengan hasil analisis hipotesis pertama, yaitu terdapat pengaruh yang signifikan penggunaan pendekatan konstruktivisme terhadap aktivitas belajar dalam pembelajaran teks biografi pada siswa kelas VIII di SMP Harapan Nusantara. (3) Putrayasa (2013) menyatakan bahwa tingkat penguasaan siswa tentang objek dan adverbial yang diajarkan dengan pendekatan konstruktivisme berbasis inkuiri lebih baik daripada siswa yang diajarkan dengan model konvensional. Penelitian ini sejajar dengan hasil analisis hipotesis kedua, yaitu terdapat pengaruh yang signifikan penggunaan pendekatan konstruktivisme terhadap hasil belajar dalam pembelajaran teks biografi pada siswa kelas VIII di SMP Harapan Nusantara. (4) Wawan Gunawan (2012) menyatakan pemilihan bahan ajar dan penggunaan pendekatan konstruktivisme dalam pembelajaran sangat efektif untuk meningkatkan hasil belajar. Penelitian ini sejajar dengan hasil analisis hipotesis kedua, yaitu terdapat pengaruh yang signifikan penggunaan pendekatan konstruktivisme terhadap hasil belajar dalam pembelajaran teks biografi pada siswa kelas VIII di SMP Harapan Nusantara. (5) Supriyadi (2014) menyatakan pendekatan konstruktivisme terbukti dapat meningkatkan kemampuan mahasiswa menulis karya ilmiah, baik pada proses maupun hasil. Hasil penelitian ini sejajar dengan hasil analisis hipotesis yang ketika, yaitu terdapat pengaruh yang signifikan penggunaan pendekatan konstruktivisme terhadap aktivitas dan hasil belajar siswa dalam pembelajaran teks biografi pada siswa kelas VIII di SMP Harapan Nusantara. Berdasarkan beberapa penelitian yang relevan dengan mata pelajaran dan tempat yang berbeda, seperti halnya yang penulis teliti bahwa pendekatan konstruktivisme memiliki pengaruh terhadap aktivitas dan hasil belajar siswa dalam menyusun teks biografi.

Dalam penelitian ini ditemukan hasil dari penggunaan pendekatan konstruktivisme lebih baik daripada model pembelajaran konvensional dan telah disejajarkan dengan hasil-hasil penelitian yang sebelumnya. Keunggulan pendekatan konstruktivisme daripada metode pembelajaran konvensional dalam pembelajaran juga dapat dilihat dari segi teoritik. Secara toeritik jika dilihat dari filosofinya, pendekatan konstruktivime didasari oleh teori belajar penemuan yang menyarankan agar siswa hendaknya belajar melalui partisipasi aktif dengan konsep-konsep dan prinsip-prinsip agar mereka memperoleh pengalaman dan melakukan eksperimen-eksperimen yang mengijinkan mereka untuk menemukan konsep dan prinsip itu sendiri. Pengetahuan yang ditemukan dengan konsep mereka sendiri lebih baik dari pada siswa menemukan pengetahuan melalui konsep orang lain. Ini sejalan dengan bahwa pembelajaran model konstruktivisme memandang belajar itu sebagai proses modifikasi ide dan pengetahuan yang telah dimiliki oleh siswa menuju terbentuknya pengetahuan baru. Dalam proses ini siswa secara aktif terlibat dalam upaya penemuan makna dari apa yang dipelajarinya sehingga secara langsung berdampak pada tumbuh dan berkembangnya keterampilan berpikir mereka selama pembelajaran berlangsung (Putrayasa, 2011).

Pada pembelajarn konvensional, siswa diharapkan telah siap secara mental untuk menerima apa yang diberikan guru atau mengikuti apa yang akan dilakukan oleh guru. Guru biasanya melakukan ekspositori dengan mendemonstrasikan sesuatu untuk menjelaskan konsep, prinsip, hukum, dan teori- 
teori tertentu. Misalnya dalam pembelajaran, guru biasanya menjelaskan suatu konsep secara naratif melalui ceramah, kemudian membuktikan hukum itu melalui demonstrasi dan selanjutnya mendiskusikan aplikasi dari hukum itu dalam kehidupan sehari-hari. Dalam konteks itu guru memegang kendali seluruh proses pembelajaran dan siswa mengikuti apa yang telah dirancang oleh guru (Dimyati dan Mudjiono, 2002). Pembelajaran dengan menggunakan pendekatan kosntuktivisme ditempuh dengan langkahlangkah sebagai berikut; pendahuluan, keguatan inti, dan penutup. Langka-langkah pembelajaran dengan menggunakan pendekatan konstruktivisme pada tahap pendahuluan yaitu: (1) pendidik dan peserta didik membangun konsep pembelajaran, (2) pendidik dan peserta didik melakukan tanya jawab, (3) pendidik menampung jawaban peserta didik dan memberi tanggapan, pendidik dan peserta didik menyepakati langkah-langkah kegiatan yang akan ditempuh. Langkah-langkah pembelajaran dengan menggunakan pendekatan konstruktivisme pada tahap kegiatan yaitu: (1) mengamati, siswa mengamati media pembelajaran yang ditampilkan pendidik atau melakukan pengamatan secara mandiri sesuai dengan materi pembelajaran yang bahas, (2)menanya, peserta didik bertanya kepada pendidik atau sebaliknya pendidik bertanya kepada peserta didik, (3) mengekplorasikan, peserta didik menyampaikan temuan hasil pengamatannya dan mendiskusikannya untuk mencapai sebuah kesimpulan yang didukung oleh fakta, (4) mengasosiasikan, peserta didik membandingkan hasil diskusi mereka dengan kelompok lain untuk mencapai pengetahuan yang sempurna, (5) mengkomunikasikan, peserta didik mempresntasikan hasil diskusi. Langkah penutup dalam pembelajaran dengan menggunakan pendekatan konstruktivisme, yaitu: (1) peserta didik mengemukakan kesulitan dan manfaat selama pembelajaran berlangsung, (2) peserta didik menyampaikan usulan untuk perbaikan pembelajaran berikutnya.

Berdasarkan temuan dalam penelitian ini memberikan petunjuk bahwa siswa yang belajar dengan menggunakan pendekatan konstruktivisme memiliki keunggulan dibandingkan dengan siswa yang belajar dengan model konvensional dalam hal meningkatkan aktivitas dan hasil belajar siswa.

\section{KESIMPULAN}

Penelitian ini dilatarbelakangi oleh rendahnya standar proses dan hasil belajar siswa dalam pembelajaran teks biografi pada kelas VIII di SMP Harapan Nusantara. Berdasarkan hasil tes observasi yang dilakukan untuk menilai aktivitas belajar siswa di dapatkan hasil sebagai berikut, kelas eksperimen yang menggunakan pendekatan konstruktivisme dalam proses pembelajaran teks biografi pada siswa kelas VIII di SMP Harapan Nusantara mendapat nilai dengan kriteria aktif, sedangkan kelas kontrol yang menggunakan model konvensional dalam pembelajaran teks biografi mendapat nilai dengan kriteria cukup. Rendahnya aktivitas belajar di kelas kontrol disebabkan oleh beberapa faktor, yaitu; (1) siswa pasif selama proses pembelajaran berlangsung, karena dalam pemblajaran model konvensional siswa cendrung menunggu arahan dari guru untuk melakukan aktivitas selama pembelajaran berlangsung, (2) siswa kurang mendapatkan ruang untuk ide atau gagasan yang dimilikinya, (3) siswa terlihat bosan selama proses pembelajaran berlangsung karena hanya mendengarkan guru berceramah memberikan teori tanpa ada inovasi pembelajaran yang dilakukan, (4) siswa tidak memiliki keberanian untuk mengambil kesimpulan dari pengamatan yang dilakukan, dan (5) dalam kegiatan pembelajaran guru jarang mengajak siswa untuk menemukan dan menyampaikan hasil temuannya, hal ini tentunya siswa hanya menghafal teori-teori yang sudah ada di buku.

Peneliti mencoba suatu model pembelajaran yang mampu mengatasi permasalahan aktivitas dan hasil belajar siswa dalam pembelajaran bahasa Indonesia, khususnya pada materi teks biografi. Model pembelajaran yang dimaksud adalah menggunakan pendekatan kontruktivisme untuk meningkatkan aktivitas dan hasil belajar siswa. Sejalan dengan latar belakang, tujuan penelitian ini adalah: (1) untuk mengetahui pengaruh penggunaan pendekatan konstruktivisme terhadap aktivitas belajar dalam pembelajaran teks biografi pada siswa kelas VIII di SMP Nusantra, (2) untuk mengetahui pengaruh penggunaan pendekatan konstruktivisme terhadap hasil belajar siswa dalam pembelajaran teks biografi pada siswa kelas VIII di SMP Harapan Nusantara, dan (3) untuk mengetahui pengaruh penggunaan pendekatan konstruktivisme terhadap aktivitas dan hasil belajar dalam pembelajaran teks biografi pada siswa kelas VIII di SMP Harapan Nusantara.

Penelitian ini merupakan penelitian eksperimen dengan mengambil polulasi penelitian kelas VIII dan sampel penelitian kelas VIII A sebagai kelas eksperimen dan kelas VIII B sebagai kelas kontrol. Jumlah siswa kelas eksperimen dan kelas kontrol masing-masing 40 siswa. Kelas VIII A dan Kelas VIII B dipilih dijadikan sampel penelitian karena kedua kelas ini mampu mewakili karakteristik kelas VIII di SMP Harapan Nusantara. Data yang terkumpul dari hasil penelitian ini kemudian dianalisis. Metode analisis data dipergunakan untuk mendiskripsikan data penelitian secara umum dan untuk menguji hipotesis penelitian. Pengujian hipotesis menggunakan Multivariate analysis of variance (MANOVA) dibantu dengan menggunakan SPSS-21 windows. Sebelum dilakukan uji hipotesis terlebih dahulu data yang terkumpul dianalisis dengan uji prasyarat yang meliputi; uji normalitas sebaran data; uji homogenitas varians, dan 
uji multikolinieritas/interkorelasi.

Berdasarkan analisis data, ditemukan sebagai berikut. (1) Aktivitas belajar dengan menggunakan pendekatan konstruktivisme dalam pembelajaran teks biografi pada siswa kelas VIII di SMP Harapan Nusantara dengan rata-rata 82,75 termasuk dalam kriteria aktif. (2) Aktivitas belajar dengan menggunakan model konvensional dalam pembelajaran teks biografi pada siswa kelas VIII di SMP Harapan Nusantara dengan rata-rata 72,25 termasuk dalam kriteria cukup aktif. Dari uji hipotesis yang dilakukan pada data aktivitas belajar siswa ditemukan $\mathrm{F}_{\text {hitung }}=217,914$ dan $\mathrm{F}_{\text {tabel }}=3,232$, dari analisis univariate of variance ini $\mathrm{F}_{\text {hitung }}$ lebih besar dari $\mathrm{F}_{\text {tabel }}$ maka hipotesis nol $\left(\mathrm{H}_{0}\right)$ ditolak dan hipotesis alternatif $\left(\mathrm{H}_{\mathrm{a}}\right)$ diterima. Dari penjelasan data di atas dapat disimpulkan bahwa pendekatan konstruktivisme memberikan pengaruh yang signifikan terhadap aktivitas belajar siswa. (3) Hasil belajar dengan menggunakan pendekatan konstruktivisme dalam pembelajaran teks biografi pada siswa kelas VIII di SMP Harapan Nusantara memperoleh rata-rata 84,85 termasuk dalam kriteria baik. (4) Hasil belajar dengan menggunakan model konvensional dalam pembelajaran teks biografi pada siswa kelas VIII di SMP Harapan Nusantara memperoleh rata-rata 72, 125 termasuk dalam kriteria cukup. Dari uji hipotesis yang dilakukan pada data hasil belajar siswa baik yang menggunakan pendekatan konstruktivisme maupun dengan model pembelajaran konvensional didapatkan $F_{\text {hitung }}=152,176$ dan $F_{\text {tabel }}$ $=3,232$. Berdasarkan hasil univariate tes yang dilakukan ditemukan $F_{\text {hitung }}$ lebih besar daripada $F_{\text {tabel, }}$ jadi hipotesis nol $\left(\mathrm{H}_{0}\right)$ dalam analisis penelitian ini ditolak dan hipotesis alternatif $\left(\mathrm{H}_{\mathrm{a}}\right)$ diterima. Berdasarkan hasil analisis data hasil belajar siswa dalam pembelajaran teks biografi pada kelas VIII di SMP Harapan Nusantara, maka penggunaan pendekatan konstruktivisme dalam pembelajaran teks biografi sangat tepat diterapkan untuk mendapatkan hasil belajar yang maksimal. (4) Aktivitas dan hasil belajar dalam pembelajaran teks biografi pada siswa kelas VIII di SMP Harapan Nusantara. Berdasarkan hasil uji multivariate diperoleh nilai-nilai statistik Pillai,sTrace Wilk's Lambada Hotelling's Trace, dan Roy'sLargest Root masing-masing dengan $\mathrm{F}_{\text {hitung }}=50,720$ dengan signifikasi $=0,05 \mathrm{db}_{\mathrm{a}}=2$ dan $\mathrm{db}_{\mathrm{d}}=80$ didapatkan $\mathrm{F}_{\text {tabel }}=$ 3, 232 pada taraf signifikasi $5 \%$. Dari data analisis diperoleh $\mathrm{F}_{\text {hitung }}$ lebih besar dari $\mathrm{F}_{\text {tabel, }}$ maka hipotesis nol $\left(\mathrm{H}_{0}\right)$ ditolak dan hipotesis alternatif $\left(\mathrm{H}_{\mathrm{a}}\right)$ diterima. Dari analisis data dengan uji hipotesis menggunakan statistik multi variate of varians aktivitas dan hasil belajar siswa maka dapat disimpulkan penggunaan pendekatan kosntruktivisme memiliki pengaruh yang signifikan terhadap aktivitas dan hasil belajar dalam pembelajaran teks biografi pada siswa kelas VIII di SMP Harapan Nusantara.

Setelah melakukan semua tahap penelitian, yakni mulai dari proses pembuatan proposal, pengambilan sampel, pembuatan instrumen, analisis instrumen, analisis pre-tes, perlakuan terhadap objek penelitian, analisis pos-tes, pengumpulan data, dan analisis data, maka dapat disimpulkan bahwa: 1.Terdapat pengaruh yang signifikan penggunaan pendekatan konstruktivisme terhadap aktivitas belajar dalam pembelajaran teks biografi pada siswa kelas VIII di SMP Harapan Nuasantara. Ini terbukti dari data yang didapatkan dari hasil penelitian aktivitas belajar siswa dengan menggunakan pendekatan konstruktivisme dengan nilai rata-rata sebesar 82,75 yang termasuk dalam kreteria aktif, sedangkan aktivitas belajar siswa dengan model konvensional dengan nilai rata-rata 72,25 termasuk kreteria cukup aktif. Dari data ini dapat disimpulkan bahwa pembelajaran teks biografi pada siswa kelas VIII di SMP Harapan Nusantara lebih tepat menggunakan pendekatan konstruktivisme daripadan menggunakan model pembelajaran konvensional. Terdapat pengaruh yang signifikan penggunaan pendekatan konstruktivisme terhadap hasil belajar dalam pembelajaran teks biografi pada siswa kelas VIII di SMP Harapan Nusantara. Hal ini dapat dilihat dari hasil pos-tes yang dilakukan di kelas eksperimen dengan menggunakan pendekatan konstruktivisme dan kelas kontrol dengan menggunakan model pembelajaran konvensional. Rata-rata hasil belajar siswa dengan menggunakan pendekatan kosntruktivisme dengan nilai 84, 85 termasuk dalam kreteria baik, sedangkan rata-rata hasil belajar siswa dengan menggunakan model pembelajaran konvensional sebesar 72, 125 termasuk dalam kreteria cukup. Berdasarkan hasil rata-rata, penggunaan pendekatan konstruktivisme dalam pembelajaran teks biografi lebih tepat digunakan dari pada model pembelajaran konvensional untuk mencapai hasil belajar yang maksimal. 3.Terdapat pengaruh yang signifikan penggunaan pendekatan konstruktivisme terhadap aktivitas dan hasil belajar siswa dalam pembelajaran teks biografi pada siswa kelas VIII di SMP Harapan Nusantara. Hal ini dibuktikan dari pembahasan yang ada pada bab IV yang meliputi: (1) Hasil penelitian, dalam hasil penelitian dibahas tentang deskripsi kualifikasi data dan dsitribusi frekuensi. (2) Uji prasyarat, dalam uji prasyarat dibahas tentang uji normalitas sebaran data, uji homogenitas varians, dan uji multikolinieritas/interkolerasi. (3) Uji hipotesis, (4) Pembahasan hasil penelitian, dan (5) Implikasi penelitian. Dari keseluruhan analisis data yang dibahas pada bab IV menyatakan bahwa penggunaan pendekatan konstruktivisme dalam pembelajaran teks biografi lebih tepat digunakan daripada model pembelajaran konvensional.

Beberapa saran yang dapat diungkapkan terkait dengan hasil penelitian ini adalah sebagai berikut: 1.Berdasarkan hasil data penelitian aktivitas belajar siswa khususnya dalam pembelajaran teks 
biografi dengan menggunakan pendekatan konstruktivisme hasil rata-ratanya lebih tinggi bila dibandingkan dengan aktivitas belajar siswa dengan menggunakan model pembelajaran konvensional. Berdasarkan data ini disarakan sebaiknya kepada guru pengajar bahasa Indonesia dalam pembelajaran teks biografi agar menggunakan pendekatan konstruktivisme. 2.Berdasarkan data penelitian hasil belajar siswa dalam pembelajaran teks biografi dengan menggunakan pendekatan konstruktivisme ratarata hasil belajar siswa lebih tinggi dibandingkan dengan hasil belajar siswa dengan menggunakan model pembelajaran konvensional. Berdasarkan data ini disarankan sebaiknya kepada guru pengajar bahasa Indonesia agar menggunakan pendekatan konstruktivisme dalam proses pembelajaran teks biografi. 3.Berdasarkan data penelitian aktivitas dan hasil belajar dalam pembelajaran teks biografi dengan menggunakan pendekatan konstruktivisme pada siswa kelas VIII di SMP Harapan Nusantara mendapatkan nilai rata-rata yang lebih baik daripada model pembelajaran konvensional, oleh karena itu berdasarkan hasil penelitian ini sebaiknya guru pengajar bahasa Indonesia di kelas VIII khususnya dalam pembelajaran teks biografi menggunakan pendekatan konstruktivisme untuk mendapatkan aktivitas dan hasil belajar yang maksimal. 4.Dalam memajukan dunia pendidikan perlu dilakukan inovasi-inovasi dalam pembelajaran. Inovasi sangat penting dilakukan untuk memperoleh proses pembelajaran yang memberi pengetahuan kepada siswa maupun untuk mendapatkan hasil belajar yang diharapkan. Oleh karena itu, sebagai seorang pendidik harus melakukan penelitian-penelitian pendekatan pembelajaran yang sesuai dengan karakteristik siswa dan materi pembelajaran yang akan diberikan.

\section{DAFTAR PUSTAKA}

Adnyana Ida Bagus Artha, I Gusti Putu Sutarma, I Nyoman Mandia. 2015. Pengembangan Model Dan Perangkat Pembelajaranmenulis Kreatifberbasis Metode Quantum Writing Jurnal Pendidikan Indonesia Universitas Pendidikan Ganesha vol 4 (2).

Djamarah, at.al. (1999). Stategi Belajar Mengajar. Jakarta: Rineka Cipta.

Fosnot, C.T. (1989). Equiring Teacher Equiring Learner: a Constructivist Approach for Teaching. New York: Teacher College Press.

Gagne, R. \& Briggs, L.J. (1979). Principle of Instructional Design. New York: Holt Rinchart and winstone.

Gulo, W. (2002). Strategi Belajar Mengajar. Jakarta: Grasindo.

Hadi. S. 2002. Statistik Jilid 3. Yogyakarta: Andi.

Hamalik Oemar. 2004. Evaluasi Kurikulum. Bandung: Remaja Rosdakarya.

Hamalik. O. (2005). Proses Belajar Mengajar. Jakarta: PT Bumi Aksara.

http://dunia-penelitian.blogspot.com/2011/12/macam-macam-penelitian eksperimen. Diunduh pada 20 september 2016.

http://techonly13.wordpressbudiyani.com/2009/07/03/instrument-aktivitas-belajar-siswa. Diunduh pada tanggal 29 Agustus 2016.

http://www.artikelsiana.com/2015pengertian-biografi.ciri-ciri-biografi.html. Diunduh pada 8 Agustus 2016.

http://www.astolog.com/7452/jelaskan-struktur-teks-dalam-biografi.htm. Diunduh pada 8 Agustus 2016.

Kerlinger, F. N. \& Lee. H. B. (1973). Foundation of behavioral research. Victoria: Thomson Learning.

Komarudin. (2012). "Penerapan Pendekatan Konstruktivisme Terhadap Peningkatan Hasil Belajar Bahasa Indonesia Tentang Menulis Cerita Pada Siswa Kelas V SD Negeri 03 Nangsri Kebakkeramat”

Makmun, A.S. (2003). Psikologi Pendidikan. Bandung: PT Rosda Karya Mandiri.

Palupi Purnamawati. (2010) “Pengaruh Pendekatan Konstruktivisme dalam Pembelajaran Kimia Terhadap Kemampuan berpikir Kreatif Siswa” Skripsi. UIN Syarif Hidayatullah Jakarta.

Paul Suparno, Filsafa Konstruktivisme dalam Pendidikan. (Yogyakarta:Kanisius, 1997) 
Putrayasa, I.B. (2011). Studi Penelusuran Miskonsepsi dalam Pembelajaran Tata Kalimat dengan Model Konstruktivisme Berpendekatan Inkuiri pada Siswa Kelas I SMP Negeri di Kota Singaraja, Kabupaten Buleleng, Provinsi Bali (Prosiding KIMLI, 2011)

Putrayasa, I.B. (2013). Penelusuran Miskonsepsi dalam Pembelajaran Tata Kalimat dengan Pendekatan Konstruktivisme Berbasis Inkuiri pada Siswa Kelas VII SMP Laboratorium Undiksha Singaraja.

Sadia, W. (1996). Pengembangan Model Belajar Konstruktivis dalam Pembelajaran IPA di Sekolah Menengah Pertama (SMP). Disertasi. PPS IKIP Bandung.

Santoso, Murwani.2002. Statistik Terapan (Teknik Analisis Data). Jakarta: PPS UJN.

Shymansky, J.A. \& Keyle, W.C. (1992). Establishing a Research Agenda: Critical Issu of Science Curriculum Reform. JRST.Vol.30, Issues

Smith, M.K., dkk. (2009). Teori Pembelajaran dan Pengajaran. Yogyakarta: Mirza Media Pustaka.

Sudjana. 1996. Metode Statistik Edisi 6. Bandung: Tarsito.

Sugiono, (2013) Statistika untuk Penelitian. Bandung: Alfabeta.

Suparno, Paul. Filsafat Kontruktivisme dalam Pendidkan. Yogyakarta: Penerbit Kanisius. 1996.

Supriyadi (2014) "Pengembangan Model Pembelajaran Menulis Karya Ilmiah Berpendekatan Konstruktivisme"

Susanto, Pudyo. Keterampilan Dasar Mengajar IPA Berbasis Kontruktivisme. Malang: FMIPA Universitas Negeri Malang.

Susilawati. Devi. Pengaruh Model Pembelajaran Kontruktivisme Tipe Novick terhadap pemahaman Konsep Matematika Siswa. Jakarta: Skripsi. FITK UIN Syarif Hdayatullah Jakarta. 2013.

Tim Penyusun. 2014. Buku Guru Bahasa Indonesia Wahana Pengetahuan. Kementerian Pendidikan dan Kebudayaan Republik Indonesia: Jakarta.

Trianto. Model-model Pembelajaran Inovatif Berorientasi Kontruktivisik; Konsep, Landasan Teoritis-Praktis dan Implementasinya, Jakarta: Presrasi Pustaka Publisher. 2007.

Wahyu. Tri R.N. dkk, Studi Perbandingan antara Teori Konstruktivisme dan Konsep E-Learning dalam Pembelajaran Bahasa Indonesia, Jurnal Procceding PESAT Gunadarma, Vol.2 ISSN: 1858-2559.

Wawan Gunawan (2012) "Konstruktivisme Berbasis Karakter Materi Pada Pembelajaran Bahasa Indonesia" 